\title{
Effects of altering the ratio of dietary $n-6$ to $n-3$ fatty acids on performance and inflammatory responses to a lipopolysaccharide challenge in lactating Holstein cows
}

\author{
L. F. Greco, ${ }^{*}$ J. T. Neves Neto, ${ }^{*}$ A. Pedrico, ${ }^{*}$ R. A. Ferrazza, ${ }^{*}$ F. S. Lima, ${ }^{*}$ R. S. Bisinotto, ${ }^{*}$ N. Martinez, ${ }^{*}$ \\ M. Garcia, ${ }^{*}$ E. S. Ribeiro, ${ }^{*}$ G. C. Gomes, ${ }^{*}$ J. H. Shin, ${ }^{*}$ M. A. Ballou, $†$ W. W. Thatcher, ${ }^{*}$ C. R. Staples, ${ }^{*}$ \\ and J. E. P. Santos* \\ *Department of Animal Sciences, University of Florida, Gainesville 32611 \\ †Department of Animal and Food Sciences, Texas Tech University, Lubbock 79409
}

\section{ABSTRACT}

The study was designed to evaluate the effects of altering the ratio between n- 6 and n- 3 fatty acids (FA) in the diet and the intake of these FA by lactating dairy cows on lactation performance and inflammatory acute phase responses to a challenge with lipopolysaccharide (LPS). Multiparous Holstein cows $(\mathrm{n}=45)$ were blocked based on milk yield from d 6 to d 10 postpartum and, within each block, assigned randomly to 1 of 3 dietary treatments at $14 \mathrm{~d}$ postpartum; treatments lasted for $90 \mathrm{~d}$. Diets were supplemented with a mixture of Ca salts of fish, safflower, and palm oils to create 3 different ratios of n- 6 to n- 3 FA; namely, $3.9,4.9$, or 5.9 parts of $\mathrm{n}-6$ to 1 part of n- 3 FA (R4, R5, and R6, respectively). During the first 5 wk of the study, blood was sampled weekly and analyzed for concentrations of metabolites and hormones. On d 75 postpartum, cows received an infusion of $10 \mu \mathrm{g}$ of LPS into one quarter of the mammary gland to evaluate inflammatory acute phase responses. Altering the ratio of dietary n- 6 to n-3 FA was reflected in changes in the FA composition of plasma and milk fat. Reducing the ratio of n- 6 to n-3 FA from R6 to R4 increased dry matter intake $(24.7,24.6$, and $26.1 \pm 0.5 \mathrm{~kg} / \mathrm{d}$ for R6, $\mathrm{R} 5$, and R4, respectively), with concurrent increases in yields of $3.5 \%$ fat-corrected milk $(43.4,45.4$, and $48.0 \pm$ $0.8 \mathrm{~kg} / \mathrm{d})$, milk fat $(1.53,1.60$, and $1.71 \pm 0.03 \mathrm{~kg} / \mathrm{d})$, milk true protein $(1.24,1.28$, and $1.32 \pm 0.02 \mathrm{~kg} / \mathrm{d})$, and milk lactose $(2.12,2.19$, and $2.29 \pm 0.04 \mathrm{~kg} / \mathrm{d})$. After the LPS challenge, concentrations of IL-6 in plasma increased as the ratio of n- 6 to n- 3 FA increased $(112.5,353.4$, and $365.1 \pm 86.6 \mathrm{pg} / \mathrm{mL}$ for $\mathrm{R} 4$, R5, and R6, respectively). Elevations of body temperature and somatic cell count were greater for cows fed R5 compared with those fed R4 or R6 (41.3, 40.8, and $40.8 \pm$

Received September 1, 2014.

Accepted September 20, 2014.

${ }^{1}$ Corresponding author: jepsantos@ufl.edu $0.2^{\circ} \mathrm{C} ; 4.33,3.68$, and $3.58 \pm 0.25 \times 10^{6} / \mathrm{mL}$, for $\mathrm{R} 5$, R4, and R6, respectively). Haptoglobin concentration was greatest at $24 \mathrm{~h}$ after LPS challenge for cows fed R6. Phagocytosis and oxidative burst by neutrophils collected from circulation were unaffected by dietary treatment in the first $48 \mathrm{~h}$ after intramammary LPS infusion. In conclusion, supplying the same quantity of FA in the diet of early lactation dairy cows but altering the ratio of the polyunsaturated FA of the n- 6 to n-3 families influenced lactation performance and inflammatory responses to an LPS challenge.

Key words: dairy cow, fatty acid, inflammation, lactation

\section{INTRODUCTION}

Feeding fat to lactating dairy cows generally has a positive effect on milk yield. In a recent systematic review of the literature encompassing 38 previously published studies, Rabiee et al. (2012) reported an overall increase in milk yield of approximately $1 \mathrm{~kg} / \mathrm{cow}$ per day in cows fed supplemental fat compared with those fed diets without supplemental fat. Furthermore, an extensive review of the literature on feeding fat to dairy cows showed that the benefits of fat supplementation depend on the type and amounts of FA provided, when supplementation was initiated, the proportion of forage fed, and other associative effects with basal dietary ingredients (Onetti and Grummer, 2004).

The effects of supplementing dairy cow diets with either n-6 (Harvatine and Allen, 2006; Amaral, 2008) or n-3 FA (Petit et al., 2007; Juchem et al., 2008) on lactational performance has been investigated. However, concurrent supplementation with $\mathrm{n}-6$ and n-3 FA to markedly affect the intake of both FA has not been performed. From the human literature, it often is stated that intake of PUFA should be manipulated such that specific amounts of n- 6 and n- 3 FA are consumed to maintain a "balance" between them (Papadopoulos et al., 2009). However, the amounts of $n-6$ 
and n-3 as well as the ratio between both groups of FA that would optimize lactation and health of dairy cows remain unknown. Increased intake of n- 6 FA has the potential to alter the FA profile of the phospholipids of cell membranes with increased proportions of linoleic and arachidonic acids, which in turn might alter gene expression and eicosanoid synthesis toward a proinflammatory state (Calder, 2012). On the other hand, increased intake of n-3 FA, especially eicosapentaenoic acid (EPA; C20:5 n-3) and docosahexaenoic acid (DHA; C22:6 n-3), would increase the proportion of these FA in the membrane phospholipids, which are expected to attenuate inflammatory responses (Calder, 2012). The metabolic cost of a clinical inflammation event has been investigated (Colditz, 2002), although data from cattle are scarce. In poultry, activation of inflammation with Escherichia coli LPS increased estimated lysine utilization by the immune system from 1.17 to $6.7 \%$ of the total intake (Klasing and Calvert, 1999). Oxygen consumption and glucose utilization by sheep lymphocytes doubled during the peak of immune response (Cheung and Morris, 1984). When steers were feed-restricted for $72 \mathrm{~h}$, the induction of inflammatory response by intratracheal bacterial challenge increased the splanchnic tissue utilization of amino acids by 2.67 $\mathrm{mol} / \mathrm{d}$ (Burciaga-Robles, 2009), illustrating the shift in nutrient utilization upon initiation of an inflammatory response. Therefore, it would be reasonable to speculate that animals fed a diet enriched in n- 6 FA could have increased nutrient partitioning for an immune response if the inflammatory challenge is exacerbated, whereas nutrient expenditure would be reduced if a diet enriched in n-3 FA attenuated the inflammatory responses (Gifford et al., 2012).

Fatty acids play important roles influencing the immune system of dairy cows as they can modulate immune cell function and inflammatory responses through various mechanisms. For instance, n-6 FA activate LPS-induced prostaglandin synthesis and activation of the inflammatory transcription factor, nuclear factor

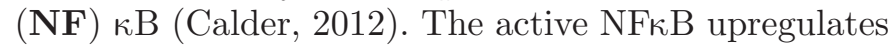
the expression of proteins that stimulate inflammation such as cytokines, chemokines, proteins involved in the acute phase response, and cell adhesion molecules (Kumar et al., 2004). On the other hand, FA of the n-3 series inhibit activation of $\mathrm{NF \kappa B}$, which further inhibits synthesis of proinflammatory proteins (Calder, 2012). Therefore, it is clear that both n-6 and n-3 FA are essential for maintaining body physiological functions. It is suggested that beyond the quantities, the balance between these 2 groups of FA appears to be important (Papadopoulos et al., 2009) and affects pro- and antiinflammatory responses, which might also be important for lactational performance.
The hypotheses were that diets containing different ratios of n- 6 to n-3 FA would influence milk production and inflammatory responses of lactating dairy cows. Specifically, increasing the n- 6 to n- 3 ratio in the diet would enhance the inflammatory response in the mammary gland after a challenge with LPS, while decreasing production. Therefore, the objectives were to determine the effect of altering the ratio of $n-6$ to n-3 FA in the diets of Holstein cows on lactation performance, metabolic status, and acute phase responses after an intramammary challenge with LPS.

\section{MATERIALS AND METHODS}

The experiment was conducted at University of Florida Dairy Unit (Hague, FL). Procedures for animal handling and care were approved by the University of Florida Animal Research Committee (ARC \# 014-11ANS).

\section{Study Design, Animals, Housing, and Feeding}

The experimental design was a randomized complete block design. Weekly cohorts of cows in their second $(\mathrm{n}=23)$ or greater $(\mathrm{n}=22)$ lactation were blocked by parity $(2$ vs. $>2$ ) and milk yield from d 6 to 10 postpartum and, within each block, randomly assigned to 1 of 3 dietary treatments at $14 \mathrm{~d}$ postpartum $(\mathrm{n}=$ 15 /treatment). Only cows that were clinically healthy (e.g., no metritis, ketosis, displacement of abomasum, or milk fever) during the first 13 DIM were eligible.

Cows were housed in a freestall barn with sand-beds and equipped with automatic feeding gates (America Calan Inc., Northwood, NH). The diet was offered as a TMR twice daily at 0730 and $1300 \mathrm{~h}$ to ensure at least $5 \%$ orts daily, and DMI was recorded for individual cows throughout the study. Four days were allowed for cows to adapt to the individual feeding gates before the treatments started. Treatments were mixed as part of the TMR and fed for $90 \mathrm{~d}$.

Three ratios of $n-6$ to $n-3$ were designed by altering the supplemental fat added to the diet to influence the intake and estimated duodenal flow of PUFA (Table 1). The first ratio was of 3.9 parts of $n-6$ to 1 part of $n-3$ FA in the diet (R4). This ratio was expected to result in a 2:1 ratio of $\mathrm{n}-6$ to $\mathrm{n}-3$ in the duodenal content based on estimates of duodenal flow of FA (CPM-Dairy ver. 3.0.8; www.cpmdairy.net). The second ratio was of 4.9 parts of $n-6$ to 1 part of n-3 in the diet (R5). This ratio was expected to result in a $4: 1$ ratio of $n-6$ to $\mathrm{n}-3$ in the duodenal contents. The final ratio was of 5.9 parts of $n-6$ to 1 part of $n-3$ in the diet (R6). This ratio was expected to result in an 8:1 ratio of $n-6$ to $n-3$ in the duodenal contents. All diets were isocaloric and isonitrogenous and contained the same total FA concen- 
tration, and were formulated to minimize the difference in concentrations of total PUFA. The FA composition of diets was manipulated by altering the mixture of Ca salts that were enriched in palm oil FA, safflower oil FA, or fish oil FA (Table 1). These Ca salts were blended such that the amount incorporated into the diets, $1.43 \%$ of dietary DM, would alter the dietary FA composition and result in the proposed ratios (Table 2). Lactation number averaged 2.7, 2.9, and $2.5 \pm 0.3$ for cows fed R4, R5, and R6, respectively.

\section{Measurements of Milk and Milk Components}

Cows were milked twice daily at 0600 and $1800 \mathrm{~h}$, and yields of milk were recorded automatically (AfiFlo milk meters, S.A.E. Afikim, Israel). Concentrations of fat, true protein, and lactose (AfiLab on-line real-time milk analyzer, S.A.E. Afikim) were recorded. Milk yield and composition from each milking were taken into account to calculate the final concentration of milk components. The calibration of the AfiLab system was performed monthly using data from milk composition of 500 University of Florida cows analyzed by the Southeast DHI laboratory (Belleview, FL). Milk corrected for $3.5 \%$ fat was calculated as follows: $\mathrm{FCM}=0.4324 \times \mathrm{kg}$ of milk $+(16.218 \times \mathrm{kg}$ of milk fat $)$.

\section{$B W, B C S$, and Calculation of Energy Balance and Feed Efficiency}

Cows were weighed twice daily, immediately after each milking, using a walk-through scale (AfiWeigh, S.A.E. Afikim) and BW was averaged daily. Once a week, body condition of cows was scored using a 5-point scale $(1=$ thin to $5=$ obese $)$ divided into 0.25 points according to Ferguson at al. (1994), as depicted in the Elanco BCS chart (Elanco Animal Health, 2009). The same person evaluated BCS throughout the study to minimize nuisance variation.

Energy balance was calculated using the formula of caloric intake (DM intake $\times \mathrm{NE}_{\mathrm{L}}$ of diet) minus the calories required for maintenance and the calories required for milk production using the equations from NRC (2001). Requirements for $\mathrm{NE}_{\mathrm{L}}$ of maintenance were based on BW $\left(0.08 \times \mathrm{BW}^{0.75}\right)$, and those for milk synthesis were according to milk yield and the concentrations of fat, protein, and lactose in milk using the following formula: $\mathrm{NE}_{\mathrm{L}}$ milk $=(0.0929 \times \%$ milk fat $)+$ $(0.0563 \times \%$ milk true protein $)+(0.0395 \times \%$ lactose $)$. Gross feed efficiency was calculated considering 3.5\% FCM yield and DMI (3.5\% FCM/DMI).

\section{Blood Metabolites and Hormones}

Blood was sampled on the same day each week during the first 5 wk of the study. Samples were collected from the coccygeal vessels using evacuated tubes containing $\mathrm{K}_{2}$ EDTA (Vacutainer, Becton Dickinson, Franklin Lakes, NJ) and placed immediately in ice. Plasma was separated by centrifugation at 2,095 $\times g$ (Allegra X15R centrifuge, Beckman Coulter Inc., Brea, CA) for 15 min and then stored at $-20^{\circ} \mathrm{C}$ for further analyses.

Plasma was analyzed for concentrations of NEFA according to Johnson and Peters (1993) using a commercial kit (NEFA-C kit; Wako Fine Chemical Industries Inc., Dallas, TX), and BHBA (Autokit 3-HB cyclic enzymatic method; Wako Diagnostics, Richmond, VA). The intra- and interassay CV were 4.6 and $8.0 \%$ for NEFA, and 3.2 and $6.4 \%$ for BHBA, respectively.

Urea $\mathrm{N}$ in plasma was analyzed with a Technicon Autoanalyzer (Technicon Autoanalyzer Instruments Corp., Chauncey, NY) using a modification of Coulombe and Favreau (1963) and Marsh et al. (1965). Glucose was analyzed using a Technicon Autoanalyzer following a modification of the method by Gochman and Schmitz (1972). The intra- and interassay CV were 6.8 and $7.5 \%$ for plasma urea $\mathrm{N}$, and 2.1 and $2.6 \%$ for glucose, respectively. Insulin concentration in plasma was measured using a double-antibody RIA following the assay protocol described by Badinga et al. (1991); the intra- and interassay CV were 13.2 and $16.1 \%$, respectively. Insulin-like growth factor was assayed using a commercial kit (Quantikine ELISA; Human IGF-1 Immunoassay; R\&D Systems Inc., Minneapolis, MN), according to the manufacturer's instructions; the intraand interassay CV were 5.4 and $6.9 \%$, respectively.

\section{Diet and Ingredient Sampling and Chemical Analyses}

Samples of forages, concentrate mixtures, and fat supplements were collected weekly, dried at $55^{\circ} \mathrm{C}$ and moisture loss recorded. Dried samples were composited monthly and ground to pass the 1-mm screen of a Wiley mill (Thomas Scientific, Swedesboro, NJ). Samples were then analyzed for DM $\left(105^{\circ} \mathrm{C}\right.$ for $\left.12 \mathrm{~h}\right)$, OM $\left(512^{\circ} \mathrm{C}\right.$ for $8 \mathrm{~h}$ ), sequential analysis of NDF using a heat-stable $\alpha$-amylase and ADF (Van Soest et al., 1991) with the Ankom Fiber Analyzer system (Ankom Technology, Macedon, NY), and $\mathrm{N}$ using an automated quantitative combustion digestion method (Elementar Analysensysteme, Elementar Americas Inc., Mt. Laurel, NJ). The energy density of the diet was estimated using chemical analysis of dietary components and calculated for $24 \mathrm{~kg}$ of DMI using the NRC (2001) model (Table 1).

\section{Blood and Milk Sampling and FA Analyses of Plasma, Milk, and Diets}

Blood was sampled at approximately 60 DIM by puncture of the coccygeal vessels into evacuated tubes 
Table 1. Dietary ingredients and nutrient composition of diets

\begin{tabular}{|c|c|c|c|}
\hline \multirow[b]{2}{*}{ Item } & \multicolumn{3}{|c|}{ Treatment $^{1}$} \\
\hline & $\mathrm{R} 4$ & R5 & $\mathrm{R} 6$ \\
\hline \multicolumn{4}{|l|}{ Ingredient, ${ }^{2} \%$ of DM } \\
\hline Corn silage & 18.7 & 18.7 & 18.7 \\
\hline Bermuda silage & 9.0 & 9.0 & 9.0 \\
\hline Alfalfa hay & 6.1 & 6.1 & 6.1 \\
\hline Corn grain, finely ground & 13.8 & 13.8 & 13.8 \\
\hline Citrus pulp & 10.1 & 10.1 & 10.1 \\
\hline Soybean hulls & 20.3 & 20.3 & 20.3 \\
\hline Soybean meal, solvent extract & 10.1 & 10.1 & 10.1 \\
\hline Soybean meal, cooker-processing ${ }^{3}$ & 5.7 & 5.7 & 5.7 \\
\hline Molasses & 1.6 & 1.6 & 1.6 \\
\hline Vitamin-mineral-protein premix ${ }^{4}$ & 3.0 & 3.0 & 3.0 \\
\hline Ca salts of palm oil ${ }^{5}$ & 0.73 & 0.65 & 0.53 \\
\hline Ca salts of safflower oil ${ }^{6}$ & 0 & 0.37 & 0.70 \\
\hline Ca salts of fish oil ${ }^{7}$ & 0.70 & 0.41 & 0.20 \\
\hline \multicolumn{4}{|l|}{ Nutrient, DM basis $( \pm \mathrm{SD})$} \\
\hline $\mathrm{NE}_{\mathrm{L}},{ }^{8} \mathrm{Mcal} / \mathrm{kg}$ & 1.62 & 1.62 & 1.62 \\
\hline $\mathrm{CP}, \%$ & $16.6 \pm 0.8$ & $16.6 \pm 0.8$ & $16.5 \pm 0.8$ \\
\hline Starch, \% & 17.3 & 17.3 & 17.3 \\
\hline $\mathrm{NFC},{ }^{9} \%$ & $35.4 \pm 1.9$ & $35.4 \pm 2.0$ & $35.5 \pm 1.9$ \\
\hline $\mathrm{ADF}, \%$ & $16.0 \pm 0.9$ & $15.9 \pm 0.9$ & $15.6 \pm 0.9$ \\
\hline $\mathrm{NDF}, \%$ & $38.4 \pm 2.3$ & $38.4 \pm 2.3$ & $38.1 \pm 2.3$ \\
\hline NDF from forage, $\%$ & $17.1 \pm 0.7$ & $17.1 \pm 0.7$ & $17.1 \pm 0.7$ \\
\hline Fatty acids, \% & $3.66 \pm 0.15$ & $3.82 \pm 0.17$ & $3.88 \pm 0.16$ \\
\hline $\mathrm{Ca}, \%$ & $0.87 \pm 0.07$ & $0.89 \pm 0.07$ & $0.90 \pm 0.08$ \\
\hline $\mathrm{P}, \%$ & $0.33 \pm 0.03$ & $0.33 \pm 0.03$ & $0.33 \pm 0.03$ \\
\hline $\mathrm{Mg}, \%$ & $0.31 \pm 0.02$ & $0.31 \pm 0.02$ & $0.31 \pm 0.02$ \\
\hline $\mathrm{K}, \%$ & $1.48 \pm 0.05$ & $1.48 \pm 0.05$ & $1.48 \pm 0.05$ \\
\hline $\mathrm{Cl}, \%$ & $0.29 \pm 0.03$ & $0.28 \pm 0.03$ & $0.29 \pm 0.03$ \\
\hline $\mathrm{Na}, \%$ & $0.32 \pm 0.01$ & $0.32 \pm 0.01$ & $0.32 \pm 0.01$ \\
\hline
\end{tabular}

${ }^{1}$ Treatments represent the ratio between n- 6 to n- 3 FA in the diet. $\mathrm{R} 4$ is a ratio of 3.9 parts of n- 6 to 1 part of $\mathrm{n}-3$; R5 is a ratio of 4.9 parts of $\mathrm{n}-6$ to 1 part of $\mathrm{n}-3$; $\mathrm{R} 6$ is a ratio of 5.9 parts of $\mathrm{n}-6$ to 1 part of n-3.

${ }^{2}$ Composition of ingredients: corn silage $(\mathrm{DM}=30.5 \%$; $\mathrm{OM}=95.1 \% ; \mathrm{CP}=8.2 \%$; $\mathrm{NDF}=43.0 \%$; $\mathrm{ADF}=$ $20.1 \%$, lignin $=1.5 \% ; \mathrm{FA}=3.3 \%) ;$ Bermuda silage $(\mathrm{DM}=44.8 \% ; \mathrm{OM}=93.5 \% ; \mathrm{CP}=11.3 \% ; \mathrm{NDF}=68.4 \%$; $\mathrm{ADF}=32.8 \%$, lignin $=4.3 \% ; \mathrm{FA}=1.9 \%)$; alfalfa hay $(\mathrm{DM}=91.6 \% ; \mathrm{OM}=90.6 \% ; \mathrm{CP}=16.4 \% ; \mathrm{NDF}=$ $47.7 \% ; \mathrm{ADF}=16.7 \%$, lignin $=5.3 \% ; \mathrm{FA}=2.0 \%) ;$ mixture of concentrates $(\mathrm{DM}=90.0 \% ; \mathrm{OM}=92.8 \% ; \mathrm{CP}$ $=19.7 \% ; \mathrm{NDF}=31.9 \% ; \mathrm{ADF}=12.2 \%$, lignin $=1.3 \% ; \mathrm{FA}=4.4 \%)$.

${ }^{3}$ AminoPlus (Ag Processing Inc., Omaha, NE).

${ }^{4}$ Contains (DM basis) 30.0\% ProvAAl LysAAMet (blend of blood meal and protected lysine and methionine, Venture Milling, Salisbury, MD), 28.5\% sodium sesquicarbonate, $13.0 \%$ potassium carbonate, $7.0 \%$ dicalcium phosphate, $7.0 \%$ magnesium oxide, $3.5 \%$ sodium chloride, $1.2 \%$ Availa-4 (Zinpro Co., Eden Prairie, MN), $0.3 \%$ Sel-Plex 2000 (Alltech Biotechnology, Nicholasville, KY), 0.06\% vitamin trace mineral premix, and $0.22 \%$ Rumensin 90 (Elanco Animal Health, Greenfield, IN). Each kilogram contains 27.8\% CP, 5.2\% Ca, 1.6\% P, $4.1 \% \mathrm{Mg}, 6.8 \% \mathrm{~K}, 10.7 \% \mathrm{Na}, 2.3 \% \mathrm{Cl}, 680 \mathrm{mg}$ of $\mathrm{Zn}, 235 \mathrm{mg}$ of Cu, $422 \mathrm{mg}$ of $\mathrm{Mn}, 6.6 \mathrm{mg}$ of Se, $23 \mathrm{mg}$ of Co, $13.8 \mathrm{mg}$ of I, 116,000 IU of vitamin A, 35,000 IU of vitamin D, 1,170 IU of vitamin E, and $450 \mathrm{mg}$ of monensin. ${ }^{5}$ EnerGII, Ca salts of palm oil FA (Virtus Nutrition, Corcoran, CA). FA composition, g/100 g of total FA: $\mathrm{C} 14: 0=1.2 ; \mathrm{C} 16: 0=49.6 ; \mathrm{C} 16: 1=0.16 ; \mathrm{C} 18: 0=4.3 ; \mathrm{C} 18: 1=34.7 ; \mathrm{C} 18: 2$ cis-9, cis-12 = 8.1: C20:5 cis-5, cis8,cis-11,cis-14,cis-17 = not detected (ND); C22:5 cis-7,cis-10,cis-13,cis-16,cis-19 = ND; C22:6 cis-4,cis-7,cis10, cis-13, cis-16, cis-19 $=\mathrm{ND} ; \mathrm{n}-6$ total $=8.1 ; \mathrm{n}-3$ total $=0.2$.

${ }^{6}$ Prequel21, Ca salts enriched in safflower oil FA (Virtus Nutrition). Fatty acid composition, g/100 g of total FA: $\mathrm{C} 14: 0=0.6 ; \mathrm{C} 16: 0=12.4 ; \mathrm{C} 16: 1=0.7 ; \mathrm{C} 18: 0=2.0 ; \mathrm{C} 18: 1=24.1 ; \mathrm{C} 18: 2$ cis-9, cis-12 = 51.9; C20:5 cis-5, cis-8,cis-11,cis-14,cis-17 =0.8; C22:5 cis-7,cis-10, cis-13, cis-16, cis-19=0.1; C22:6 cis-4,cis-7,cis-10,cis13, cis- 16, cis-19 $=0.4 ; \mathrm{n}-6$ total $=51.9 ; \mathrm{n}-3$ total $=2.2$.

${ }^{7}$ StrataG113, Ca salts enriched in fish oil FA (Virtus Nutrition). Fatty acid composition, g/100 g of total FA: $\mathrm{C} 14: 0=9.0 ; \mathrm{C} 16: 0=23.1 ; \mathrm{C} 16: 1=9.9 ; \mathrm{C} 18: 0=5.5 ; \mathrm{C} 18: 1=11.7 ; \mathrm{C} 18: 2-$ cis-9,cis-12 = 1.9; C20:5 cis-5, cis8, cis-11,cis-14,cis-17 = 11.9; C22:5-cis-7,cis-10,cis-13,cis-16,cis-19 = 2.0; C22:6 cis-4,cis-7,cis-10,cis-13,cis16, cis-19 $=6.3 ; \mathrm{n}-6$ total $=2.8 ; \mathrm{n}-3$ total $=20.9$.

${ }^{8} \mathrm{NE}_{\mathrm{L}}$ according to NRC (2001) using analyzed feed values and calculated at $24 \mathrm{~kg}$ of DMI/d.

${ }^{9} \mathrm{NFC}$ calculated as $100-(\mathrm{NDF}+\mathrm{CP}+\mathrm{FA}+\mathrm{ash})$. 
Table 2. Fatty acid composition of diets (mean \pm SD)

\begin{tabular}{|c|c|c|c|}
\hline \multirow[b]{2}{*}{$\mathrm{FA}, \%$ of $\mathrm{DM}$} & \multicolumn{3}{|c|}{ Treatment $^{1}$} \\
\hline & $\mathrm{R} 4$ & $\mathrm{R} 5$ & $\mathrm{R} 6$ \\
\hline C12:0 & $0.006 \pm 0.017$ & $0.006 \pm 0.015$ & $0.006 \pm 0.015$ \\
\hline C14:0 & $0.053 \pm 0.059$ & $0.045 \pm 0.037$ & $0.030 \pm 0.037$ \\
\hline C15:0 & $0.006 \pm 0.041$ & $0.006 \pm 0.040$ & $0.005 \pm 0.040$ \\
\hline C16:0 & $0.820 \pm 0.531$ & $0.824 \pm 0.418$ & $0.776 \pm 0.451$ \\
\hline C16:1 cis-9 & $0.050 \pm 0.053$ & $0.042 \pm 0.034$ & $0.027 \pm 0.036$ \\
\hline C17:0 & $0.009 \pm 0.016$ & $0.009 \pm 0.015$ & $0.008 \pm 0.015$ \\
\hline C18:0 & $0.135 \pm 0.120$ & $0.133 \pm 0.114$ & $0.127 \pm 0.116$ \\
\hline $\mathrm{C} 18: 1$ cis-9 & $0.708 \pm 0.184$ & $0.762 \pm 0.174$ & $0.785 \pm 0.194$ \\
\hline C18:2 cis- 9 , cis- 12 & $1.250 \pm 0.838$ & $1.431 \pm 0.653$ & $1.580 \pm 0.670$ \\
\hline $\mathrm{C} 18: 3$ cis- 9, cis- 12, cis- 15 & $0.238 \pm 0.181$ & $0.228 \pm 0.163$ & $0.229 \pm 0.163$ \\
\hline $\mathrm{C} 20: 0$ & $0.015 \pm 0.026$ & $0.018 \pm 0.016$ & $0.018 \pm 0.015$ \\
\hline $\mathrm{C} 20: 3$ cis-8, cis-11,cis-14 & $0.001 \pm 0.001$ & $\mathrm{ND}^{2}$ & ND \\
\hline $\mathrm{C} 20: 3$ cis-11,cis-14,cis-17 & $0.001 \pm 0.003$ & $0.001 \pm 0.001$ & ND \\
\hline C20:4 cis-5,cis-8,cis-11,cis-14 & $0.004 \pm 0.007$ & $0.003 \pm 0.007$ & $0.002 \pm 0.007$ \\
\hline C20:5 cis-5,cis-8,cis-11,cis-14,cis-17 & $0.051 \pm 0.007$ & $0.040 \pm 0.011$ & $0.023 \pm 0.008$ \\
\hline C22:4 cis-7,cis-10,cis-13,cis-16 & $0.005 \pm 0.019$ & $0.005 \pm 0.019$ & $0.005 \pm 0.019$ \\
\hline $\mathrm{C} 22: 5$ cis- 7, cis- 10, cis- 13, cis- 16, cis- 19 & $0.009 \pm 0.002$ & $0.007 \pm 0.001$ & $0.004 \pm 0.001$ \\
\hline C22:6 cis-4,cis-7,cis-10,cis-13,cis-16,cis-19 & $0.028 \pm 0.006$ & $0.022 \pm 0.009$ & $0.013 \pm 0.005$ \\
\hline Others & $0.275 \pm 0.524$ & $0.225 \pm 0.517$ & $0.241 \pm 0.592$ \\
\hline $\mathrm{n}-6$ total & $1.260 \pm 0.10$ & $1.447 \pm 0.08$ & $1.587 \pm 0.08$ \\
\hline n-3 total & $0.327 \pm 0.01$ & $0.298 \pm 0.01$ & $0.269 \pm 0.01$ \\
\hline Ratio of $n-6$ to $n-3$ & 3.9 & 4.9 & 5.9 \\
\hline
\end{tabular}

containing $\mathrm{K}_{2}$ EDTA (Vacutainer, Becton Dickinson) and placed immediately in ice. Plasma was separated by centrifugation at $2,095 \times g$ for 15 min (Allegra X$15 \mathrm{R}$ centrifuge) and then stored at $-20^{\circ} \mathrm{C}$. An aliquot of $2.0 \mathrm{~mL}$ was freeze-dried (Labconco, Kansas City, $\mathrm{MO})$.

The FA isolation and methylation of the concentrates, forages, fat supplements, and freeze-dried plasma samples were performed according to Kramer et al. (1997). Fatty acid methyl esters were determined using a Varian CP-3800 gas chromatograph (Varian Inc., Palo Alto, CA) equipped with an auto-sampler (Varian CP-8400), flame-ionization detector, and a Varian capillary column (CP-Sil 88, $100 \mathrm{~m} \times 0.25 \mathrm{~mm} \times 0.2 \mu \mathrm{m})$. The carrier gas was He, the split ratio was 10:1, and the injector and detector temperatures were maintained at $250^{\circ} \mathrm{C}$. One microliter of sample was injected via the auto-sampler onto the column. The oven temperature was set initially at $70^{\circ} \mathrm{C}$ for $3 \mathrm{~min}$, increased by $30^{\circ} \mathrm{C} /$ min up to $162^{\circ} \mathrm{C}$, increased by $0.5^{\circ} \mathrm{C} / \mathrm{min}$ up to $165^{\circ} \mathrm{C}$, increased by $0.6^{\circ} \mathrm{C} / \mathrm{min}$ up to $195^{\circ} \mathrm{C}$, held at $195^{\circ} \mathrm{C}$ for $20 \mathrm{~min}$, increased by $3.5^{\circ} \mathrm{C} / \mathrm{min}$ up to $220^{\circ} \mathrm{C}$, and held at $220^{\circ} \mathrm{C}$ for $6 \mathrm{~min}$. The peaks were identified and calculated based on the retention time and peak area of known standards.

Milk samples from 4 consecutive milkings at wk 10 of the study were collected and stored at $-20^{\circ} \mathrm{C}$ without preservative for analysis of FA. Samples were thawed and composited based on the yield of each milking sampled, and then centrifuged at $17,800 \times g$ for 30 min at $8^{\circ} \mathrm{C}$ to isolate the milk fat. The milk fat cake was analyzed for FA profile at Clemson University. The FAME were obtained following the procedures of O'Fallon et al. (2007). Individual FA were identified using a Shimadzu 2010 plus gas chromatograph (Shimadzu America Inc., Columbia, MD). The carrier gas was $\mathrm{H}$, the split ratio was 5:1, and the injector and detector temperatures were maintained at $240^{\circ} \mathrm{C}$; 1 to $3 \mu \mathrm{L}$ of sample was injected onto the column. The oven temperature was initially set to $125^{\circ} \mathrm{C}$ for $2 \mathrm{~min}$, increased by $0.5^{\circ} \mathrm{C} / \mathrm{min}$ up to $155^{\circ} \mathrm{C}$, increased by $2^{\circ} \mathrm{C} /$ min up to $235^{\circ} \mathrm{C}$, and maintained for $13 \mathrm{~min}$. The standards used to identify the peaks were GLC-603, GLC484, and GLC-90 (Nu-Chek Prep Inc., Elysian, MN). The apparent transfer efficiency of dietary FA to milk was calculated by dividing the amount of the selected FA in milk fat by the amount the FA ingested during wk 10 of the study.

\section{Acute Phase Responses to a LPS Challenge}

On d 75 postpartum, cows with $\mathrm{SCC}<300,000 / \mathrm{mL}$ in the preceding $10 \mathrm{~d}$ were eligible to undergo an intramammary challenge with LPS. Of the 45 cows, 39 were selected, 13 per dietary treatment. On the day of infusion, mammary quarters had milk evaluated for 
SCC after the morning milking using the California Mastitis Test reaction (CMT kit; ImmuCell Corp., Portland, ME). Only quarters negative by California Mastitis Test were used for infusion and for controls. Approximately $3 \mathrm{~h}$ after the morning milking, $10 \mu \mathrm{g}$ of LPS (Escherichia coli O111:B4; Sigma L2630, Sigma Aldrich, St. Louis, MO) diluted in $10 \mathrm{~mL}$ of sterile PBS was infused via the teat canal in one randomly selected quarter. Milk samples were collected at $0,2,4,6,8,14$, $24,48,72$, and $96 \mathrm{~h}$ after infusion. Milk was sampled from the infused quarter separately from others. Milk from the noninfused quarters was composited. Samples were preserved with bronopol-B-14 and analyzed for SCC by the Southeast Milk Laboratory (Belleview, FL) using a Bentley 2000 mid-infrared spectrophotometer analyzer (Bentley Instruments Inc., Chaska, MN).

Blood was collected from the coccygeal vessels at $0,2,4,8,14,24$, and $48 \mathrm{~h}$ after the LPS infusion. Harvested plasma $(2,095 \times g$ for $15 \mathrm{~min}$, Allegra X$15 \mathrm{R}$ centrifuge) was frozen and later analyzed for concentrations of the acute phase proteins haptoglobin (Makimura and Suzuki, 1982) and acid-soluble protein. Briefly, acid-soluble protein was extracted with $0.6 \mathrm{M}$ perchloric acid (Fisher Scientific, Hampton, NH) diluted in distilled water $(66 \mathrm{~mL}$ of perchloric acid in $1 \mathrm{~L}$ of water). Plasma samples $(50 \mu \mathrm{L})$ were incubated with perchloric acid solution $(1 \mathrm{~mL})$ for $20 \mathrm{~min}$ at room temperature. Samples were then centrifuged $(2,095 \times g$ for 30 min, Allegra X-15R centrifuge). Bicinchoninic acid kit (Sigma-Aldrich) was used to analyze the protein concentration in the supernatant. The concentrations of cytokines IFN- $\gamma$ and IL-6 were measured in plasma using a multiplex chemiluminescent assay following the manufacturer's procedures (Ciraplex Chemiluminescent Assay Kit 29-038-1-AB; Aushon BioSystems, Billerica, MA). Concurrent samples were collected at 4, 14, 24, and $48 \mathrm{~h}$ after the challenge to evaluate neutrophil phagocytic and oxidative burst activities, using methodology adapted from Smits et al. (1997) using a dualcolor flow cytometry assay as described by Martinez et al. (2012). Rectal temperature was measured at 0, 2, 4, $8,14,24$, and $48 \mathrm{~h}$ after the LPS infusion.

\section{Statistical Analysis}

Data were analyzed using the GLIMMIX procedure of SAS (version 9.2, SAS Institute Inc., Cary, NC) fitting either a normal or Poisson distribution according to the type of data. Continuous data were analyzed for normality of residuals before statistical analyses. When residuals were not normally distributed, transformation was applied and evaluated to determine if model fit was improved. Daily results were averaged into weekly means before analyses. Data for milk production and composition, BW, BCS, DMI, and energy balance were analyzed including a pretreatment covariate value that was measured before treatments were initiated, when cows were fed a common diet. All models included the fixed effects of treatment, parity ( 2 or $>2)$, and interactions between treatment and parity. Models for data with repeated measurements over time within the same experimental unit also included the fixed effects of time and interaction between treatment and time, and the random effect of cow nested within treatment. The time reference for the statistical models was either day or week relative to the beginning of the study or hour relative to challenge with LPS. Whenever treatment effect was detected, pairwise comparisons were performed with adjustment by the method of Tukey. For models with repeated measures within experimental unit, the covariance structure (compound symmetry, heterogeneous compound symmetry, autoregressive 1, heterogeneous autoregressive 1, or Toeplitz) that resulted in the lowest Akaike's information criterion was selected. For unequally spaced measurements, the spatial power covariance structure was used.

Significance of the differences was declared when $P$ $\leq 0.05$ and a tendency to differ when $0.05<P \leq 0.10$.

\section{RESULTS}

Chemical analyses of dietary ingredients and the rations fed to cows indicated minor deviations from the preplanned ratios of n- 6 to n- 3 FA in the diet (Table 1 ). The diets contained ratios of $3.9,4.9$, and 5.9 for R4, R5, and R6, respectively, and differed in the FA profile, particularly in concentrations of linoleic, EPA, and DHA (Table 2).

\section{$D M I, B W$, and $B C S$}

Intake of DM increased $(P=0.05)$ with feeding $\mathrm{R} 4$ compared with R5 or R6 (Table 3; Figure 1A). Based on diet composition and intake of DM, total FA intake did not differ and averaged $953 \pm 24 \mathrm{~g} / \mathrm{d}$. An effect $(P<0.001)$ of treatment was detected for intakes of n- 6 and n-3 FA (Table 3). As the ratio of n-6 to n-3 FA increased, intakes of linoleic and total n- 6 FA also increased. Conversely, as the ratio of n- 6 to n- 3 decreased, the intake of EPA and DHA and total n-3 FA increased (Table 3).

Cows fed all diets lost body condition immediately before enrollment in the study. From wk 3 to 15 postpartum, cows lost approximately 0.2 units of body condition. Treatment had minor effects on BCS of cows, and those fed R4 tended $(P=0.07)$ to have lower BCS than cows fed R5 after wk 7 postpartum. No difference in BCS was observed between R5 and R6 or between 
Table 3. Effect of altering the dietary ratio of n-6 to n-3 FA on intake, lactation performance, and energy balance

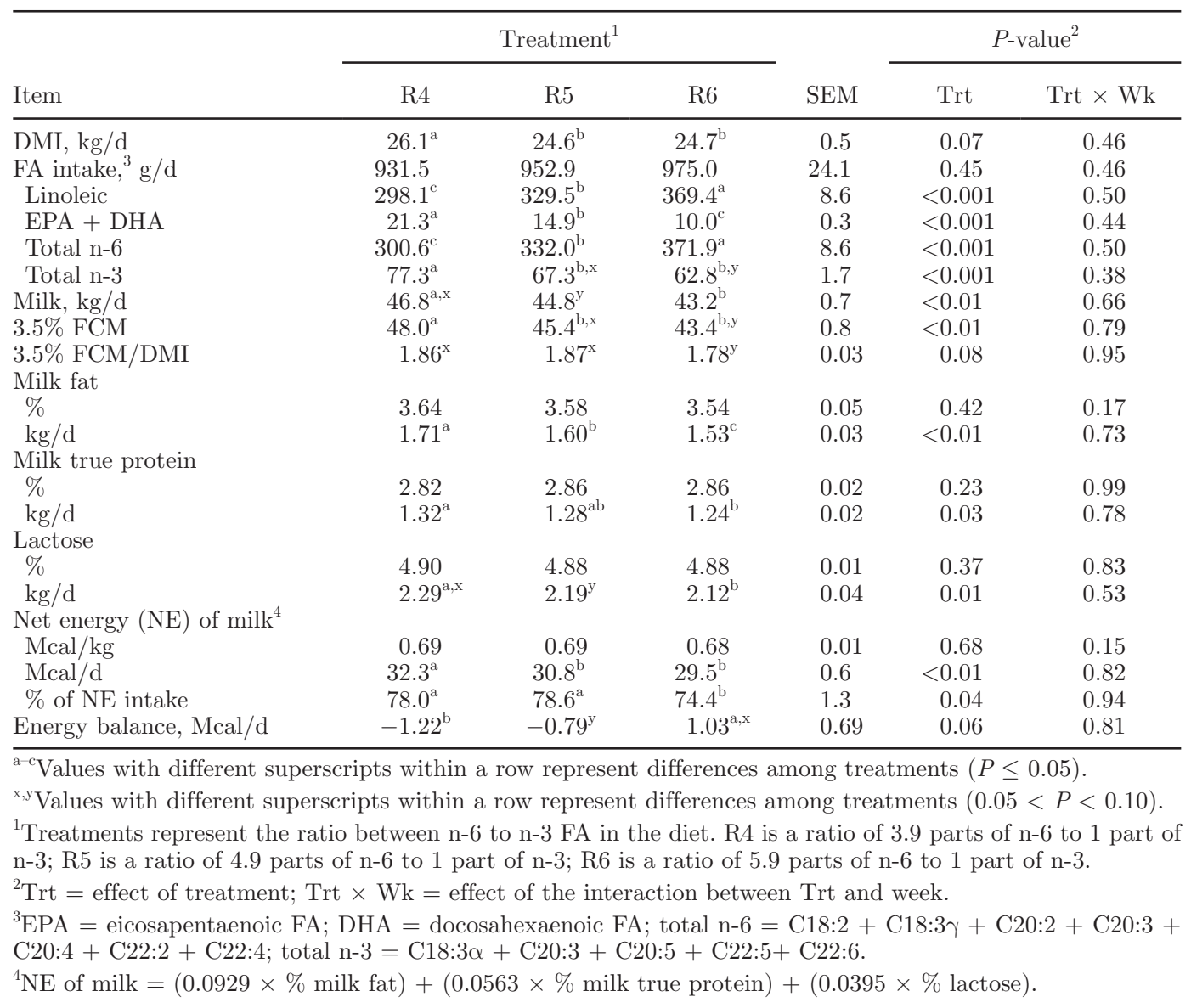

R4 and R6 (Figure 1E). Similar to BCS, cows lost BW immediately before enrollment into treatments, but BW of cows remained stable throughout the experimental period and was unaffected by dietary treatments (Figure $1 \mathrm{~F})$. From wk 3 to 15 postpartum, the BW of cows averaged $627 \pm 6 \mathrm{~kg}$.

\section{Milk Production and Composition, Energy Balance, and Feed Efficiency}

Yields of milk, 3.5\% FCM, milk fat, milk true protein, and lactose all increased $(P<0.001)$ as the ratio of n- 6 to n-3 FA decreased from R6 to R4 (Table 3). In fact, $3.5 \%$ FCM increased with R4, and this response was consistent throughout the duration of the study (Figure 1B). Efficiency of feed conversion into $3.5 \%$ FCM tended to increase $(P=0.08)$ as the ratio of $\mathrm{n}-6$ to n-3 FA decreased (Table 3; Figure 1C). Concentrations of fat, true protein, and lactose in milk were not affected by treatment. The similar milk composition across treatments resulted in no dietary treatment effect on the caloric content of milk, which averaged
$0.69 \pm 0.01 \mathrm{Mcal} / \mathrm{kg}$. Nevertheless, the increased milk nutrient output as cows consumed more n-3 and less n-6 FA resulted in an increase $(P<0.01)$ in the amount of calories secreted as milk (Table 3 ), observed primarily in cows fed the R4 diet. In spite of increased DMI by cows fed $\mathrm{R} 4$, the greater milk nutrient secretion resulted in a decrease $(P=0.06)$ in net energy balance as the ratio of n- 6 to n-3 FA decreased in the diet (Table 3 ). Cows in all treatments were in negative energy balance until wk 7 postpartum, after which cows averaged a positive energy balance of $1.9 \mathrm{Mcal} / \mathrm{d}$ (Figure 1D). Throughout the study, cows fed R6 had a consistently greater energy balance compared with cows fed R4.

\section{Metabolic and Hormonal Responses}

During the first $5 \mathrm{wk}$ of the study, corresponding to wk 3 to 7 postpartum, mean plasma concentrations of glucose, BHBA, insulin, and IGF-1 were not affected by treatments (Figure 2). Cows fed R5 had a lower mean concentration of urea $\mathrm{N}$ in plasma compared with cows fed R4 and R6 diets $(P=0.04$, Figure 2B). As the 

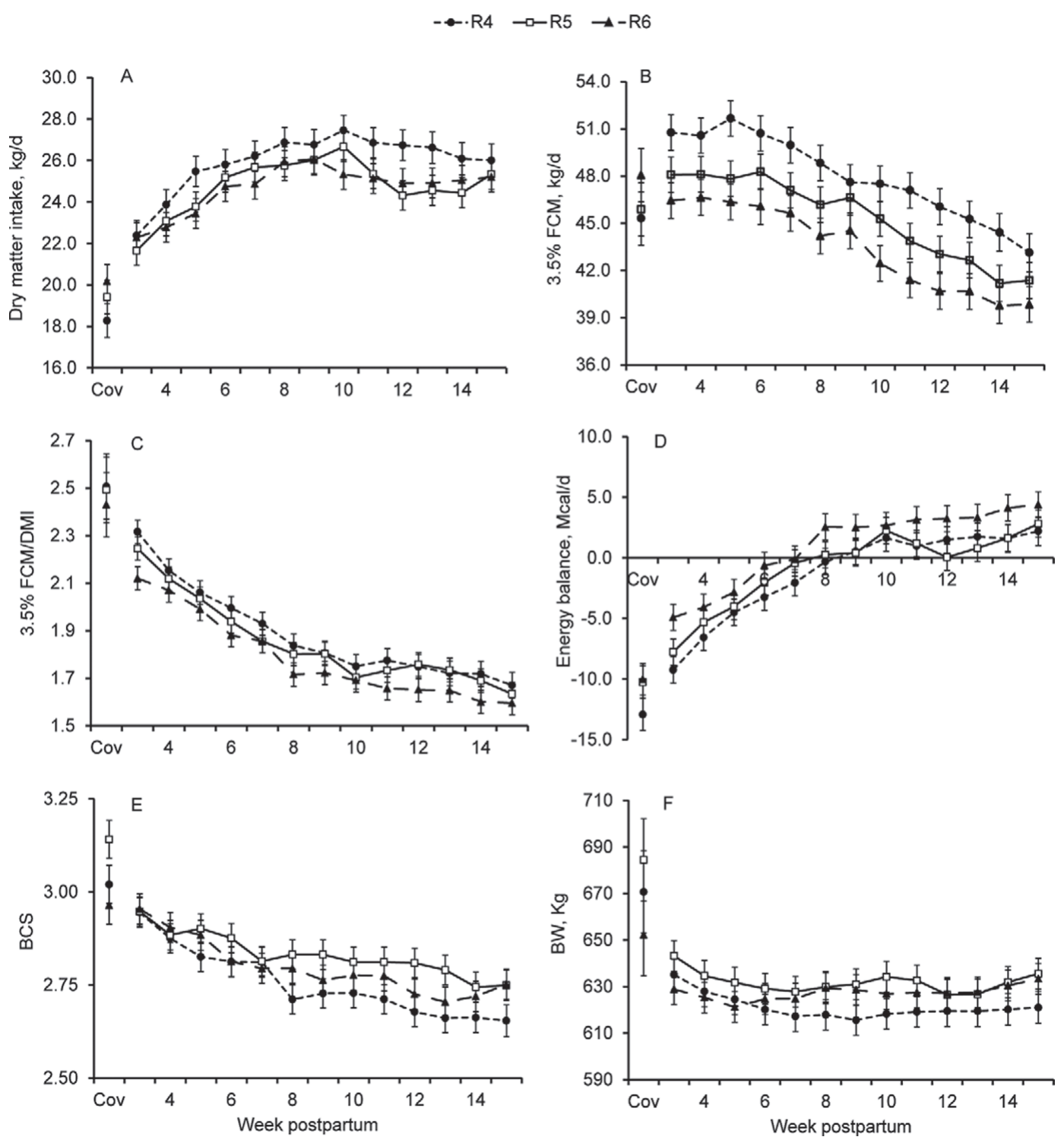

Figure 1. (A) DMI, (B) 3.5\% FCM, (C) feed conversion ratio of $\mathrm{kg}$ of $3.5 \% \mathrm{FCM} / \mathrm{kg}$ of DMI, (D) energy balance, (E) BCS, and (F) BW of lactating Holstein cows fed diets of 3.9 to 1 (R4), 4.9 to 1 (R5), or 5.9 to 1 (R6) ratios of n-6 to n-3 FA. Cov = covariate value measured between 6 and 10 DIM.

ratio n-6 to n-3 in the diet decreased, the mean plasma concentrations of NEFA tended $(P=0.10)$ to increase (Figure 2C).

\section{FA Profile of Plasma and Milk}

The FA profile of plasma followed similar changes as FA intake (Table 4). Increasing linoleic acid intake by feeding a greater ratio of $n-6$ to $n-3$ in the diet tended $(P=0.08)$ to enhance the proportion of linoleic acid in plasma. Similarly, the longer chain n-3 FA (EPA and DHA) were a greater $(P<0.001)$ proportion of the plasma FA as the dietary ratio of n- 6 to n- 3 decreased from $\mathrm{R} 6$ to $\mathrm{R} 4$. Because the changes in concentrations of n- 6 and n-3 FA in plasma followed those imposed by the dietary treatments, the resulting ratio of plasma n-6 to n-3 FA increased $(P<0.001)$ from 7.6 to $11.3 \pm$ 0.40 as the dietary treatment changed from R4 to R6 (Table 4). Interestingly, the proportion of arachidonic acid in plasma was similar among treatments despite the differences in intake of n- 6 FA.

The proportions of de novo synthesized FA (those with $<16$ carbons) and preformed FA (those with $>16$ carbons) in milk fat remained unaffected by the changes in dietary intake of n-6 and n-3 FA (Table 5). We detected no differences in the degree of unsaturation or concentrations of SFA and MUFA in milk fat by altering the ratio of n- 6 to n- 3 FA in the diet. However, 

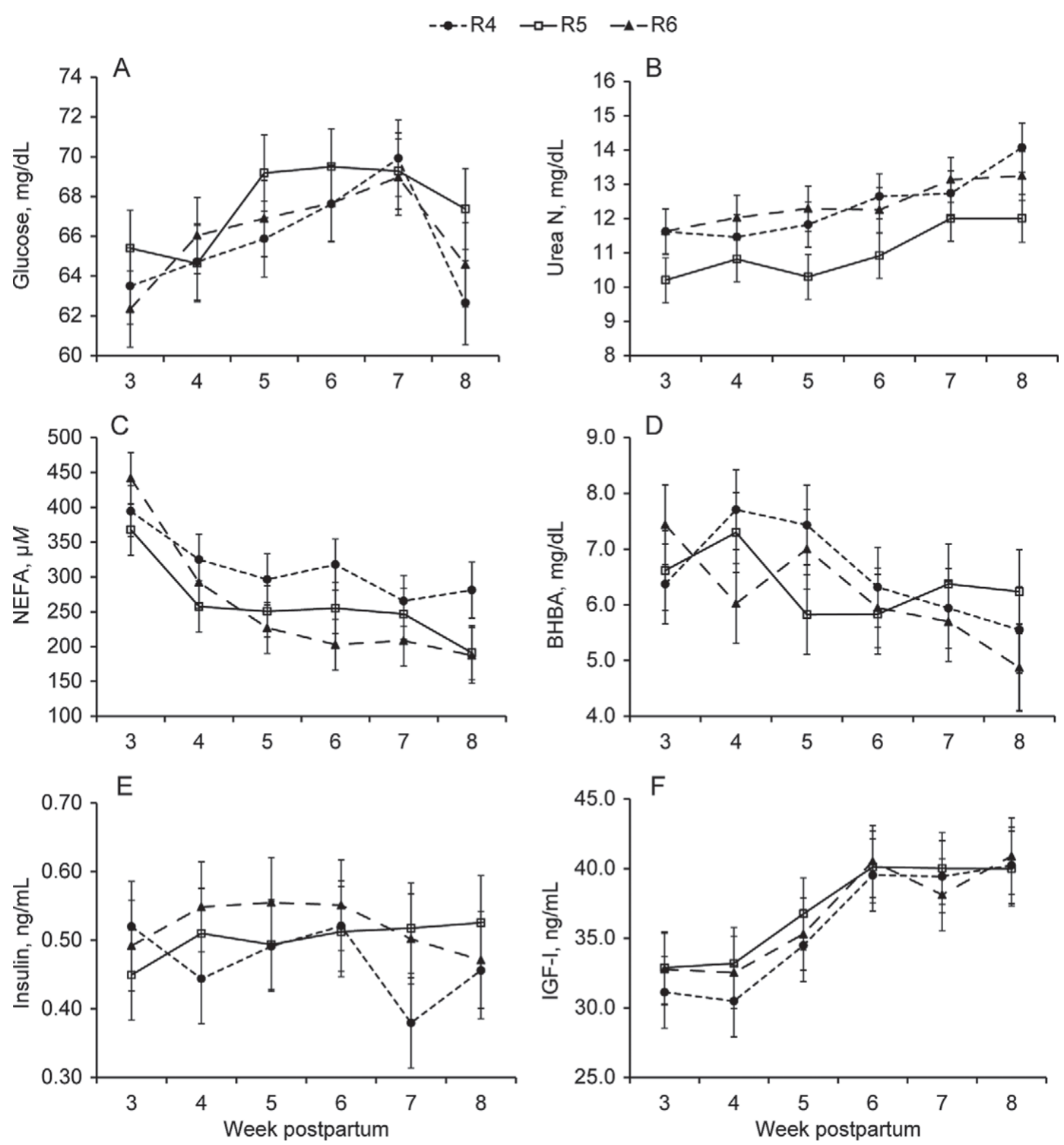

Figure 2. Concentrations of glucose $(\mathrm{A} ; \mathrm{R} 4=65.7, \mathrm{R} 5=67.5$, and $\mathrm{R} 6=66.1 \pm 1.1 \mathrm{mg} / \mathrm{dL}$; effect of treatment: $P=0.46$; interaction between treatment and week: $P=0.74)$, urea $\mathrm{N}(\mathrm{B} ; \mathrm{R} 4=12.4$, R5 $=11.0$, and $\mathrm{R} 6=12.4 \pm 0.4 \mathrm{mg} / \mathrm{dL}$; effect of treatment: $P=0.04$; interaction between treatment and week: $P=0.85$; R4 vs. R5: $P=0.03 ; \mathrm{R} 4$ vs. R6: $P=0.93$; R5 vs. R6: $P=0.02)$, NEFA $(\mathrm{C} ; \mathrm{R} 4=310.8, \mathrm{R} 5=$ 256.7, and R6 $=247.9 \pm 22.5 \mu M$; effect of treatment: $P=0.10$; interaction between treatment and week: $P=0.52 ; \mathrm{R} 4$ vs. R5: $P=0.09$; R4 vs. R6: $P=0.06$; R5 vs. R6: $P=0.79$ ), BHBA (D; R4 $=6.51$, R5 $=6.34$, and R6 $=6.11 \pm 0.47 \mathrm{mg} / \mathrm{dL}$; effect of treatment: $P=0.83$; interaction between treatment and week: $P=0.13$ ), insulin $(\mathrm{E} ; \mathrm{R} 4=0.47, \mathrm{R} 5=0.50$, and $\mathrm{R} 6=0.52 \pm 0.05$; effect of treatment: $P=0.73 \mathrm{ng} / \mathrm{mL}$; interaction between treatment and week: $P=0.53)$, and IGF-1 $(\mathrm{F} ; \mathrm{R} 4=35.65, \mathrm{R} 5=37.02$, and R6 $=36.53 \pm 1.93$; effect of treatment: $P=$ 0.88; interaction between treatment and week: $P=0.99$ ) in plasma of lactating Holstein cows fed diets of 3.9 to 1 (R4), 4.9 to 1 (R5), or 5.9 to 1 (R6) ratios of n-6 to n-3 FA.

increasing the ratio from $\mathrm{R} 4$ to $\mathrm{R} 6$ resulted in an increase $(P=0.03)$ in $\mathrm{n}-6 \mathrm{FA}$ in milk fat, and most of this increase was due to changes in linoleic acid. Concurrent with the increase in n-6 FA in milk fat, increasing the dietary ratio from $\mathrm{R} 4$ to $\mathrm{R} 6$ did not alter $(P=0.23)$ the concentration of total n-3 FA in milk fat. However, the concentrations of EPA decreased $(P<0.01)$ as the dietary ratio increased from $\mathrm{R} 4$ to $\mathrm{R} 6$.
The apparent transfer efficiency for dietary linoleic acid into milk fat was not affected $(P=0.76)$ by changes in the intake of linoleic acid and averaged 12.7 $\pm 0.9 \%$. Similarly, dietary treatments did not affect $(P$ $=0.67$ ) the transfer efficiency of total n- 6 FA into milk fat, which averaged $13.6 \pm 0.9 \%$. For EPA and DHA combined, the mean transfer efficiency into milk fat increased $(P=0.03)$ with increased intake of these FA 
Table 4. Effect of altering the ratio of dietary n-6 to n-3 FA on plasma FA profile

\begin{tabular}{|c|c|c|c|c|c|}
\hline \multirow[b]{2}{*}{$\mathrm{FA}, \mathrm{g} / 100 \mathrm{~g}$ of $\mathrm{FA}$} & \multicolumn{3}{|c|}{ Treatment $^{1}$} & \multirow[b]{2}{*}{ SEM } & \multirow[b]{2}{*}{$P$-value } \\
\hline & $\mathrm{R} 4$ & R5 & $\mathrm{R} 6$ & & \\
\hline C8:0 & 0.01 & 0.01 & 0.01 & 0.01 & 0.93 \\
\hline C10:0 & 0.02 & 0.02 & 0.03 & 0.01 & 0.30 \\
\hline C12:0 & 0.01 & 0.01 & 0.01 & 0.01 & 0.65 \\
\hline C14:0 & 0.49 & 0.48 & 0.44 & 0.02 & 0.12 \\
\hline C15:0 & 0.51 & 0.500 & 0.49 & 0.02 & 0.68 \\
\hline C16:0 & $11.52^{\mathrm{a}}$ & $11.13^{\mathrm{a}}$ & $10.30^{\mathrm{b}}$ & 0.29 & 0.02 \\
\hline $\mathrm{C} 16: 1^{2}$ & 1.10 & 1.01 & 0.79 & 0.12 & 0.16 \\
\hline C17:0 & 0.67 & 0.62 & 0.68 & 0.03 & 0.26 \\
\hline $\mathrm{C} 17: 1$ cis 10 & 0.01 & 0.01 & 0.01 & 0.01 & 0.87 \\
\hline C18:0 & $11.89^{\mathrm{b}}$ & $12.32^{\mathrm{ab}}$ & $12.89^{\mathrm{a}}$ & 0.23 & 0.02 \\
\hline $\mathrm{C} 18: 1^{2}$ & 6.02 & 5.94 & 5.53 & 0.41 & 0.67 \\
\hline C18:2 cis-9,cis-12 & $47.13^{\mathrm{b}, \mathrm{y}}$ & $48.73^{\mathrm{x}}$ & $48.83^{\mathrm{a}}$ & 0.59 & 0.08 \\
\hline $\mathrm{C} 18: 3$ cis- 6, cis- 9, cis- 12 & $0.41^{\mathrm{b}}$ & $0.51^{\mathrm{b}}$ & $0.68^{\mathrm{a}}$ & 0.04 & $<0.001$ \\
\hline C18:3 cis- $9, c i s-12, c i s-15$ & $3.57^{\mathrm{a}}$ & $3.13^{\mathrm{b}}$ & $2.98^{\mathrm{b}}$ & 0.09 & $<0.001$ \\
\hline $\mathrm{C} 20: 0$ & 0.03 & 0.03 & 0.04 & 0.01 & 0.33 \\
\hline C20:2 cis-11, cis-14 & 0.08 & 0.08 & 0.08 & 0.01 & 0.37 \\
\hline $\mathrm{C} 20: 3$ cis-8, cis-11,cis-14 & $1.25^{\mathrm{b}}$ & $1.46^{\mathrm{b}}$ & $1.82^{\mathrm{a}}$ & 0.10 & 0.001 \\
\hline C20:4 cis-5,cis-8,cis-11,cis-14 & 1.98 & 1.89 & 1.90 & 0.08 & 0.67 \\
\hline $\mathrm{C} 20: 5$ cis-5,cis-8,cis-11,cis-14,cis-17 & $1.79^{\mathrm{a}}$ & $1.20^{\mathrm{b}}$ & $0.85^{\mathrm{c}}$ & 0.10 & $<0.001$ \\
\hline C22:5 cis- 7, cis-10,cis-13,cis-16,cis-19 & 0.80 & 0.78 & 0.69 & 0.09 & 0.68 \\
\hline C22:6 cis- 4, cis- 7, cis-10,cis-13,cis- 16, cis-19 & $0.52^{\mathrm{a}}$ & $0.35^{\mathrm{b}}$ & $0.24^{\mathrm{c}}$ & 0.04 & $<0.001$ \\
\hline $\mathrm{C} 24: 1$ cis-15 & 0.05 & 0.04 & 0.06 & 0.02 & 0.82 \\
\hline Other FA & 9.73 & 9.76 & 10.69 & 0.54 & 0.36 \\
\hline Total SFA & 25.15 & 25.13 & 24.87 & 0.31 & 0.77 \\
\hline Total MUFA & 7.18 & 7.00 & 6.39 & 0.50 & 0.51 \\
\hline Total PUFA & 57.93 & 58.12 & 58.06 & 0.69 & 0.98 \\
\hline Total n-6 & $50.85^{\mathrm{b}}$ & $52.66^{\mathrm{a}}$ & $53.30^{\mathrm{a}}$ & 0.54 & 0.01 \\
\hline Total n-3 & $7.09^{\mathrm{a}}$ & $5.46^{\mathrm{b}}$ & $4.76^{\mathrm{b}}$ & 0.34 & $<0.001$ \\
\hline $\mathrm{n}-6$ to $\mathrm{n}-3$ ratio & $7.60^{\mathrm{c}}$ & $9.84^{\mathrm{b}}$ & $11.3^{\mathrm{a}}$ & 0.40 & $<0.001$ \\
\hline
\end{tabular}

$(\mathrm{R} 4=4.34 \pm 0.61$ vs. $\mathrm{R} 5=4.93 \pm 0.57$ vs. $\mathrm{R} 6=2.84$ $\pm 0.55 \%)$. In spite of the effects of dietary n- 6 to n-3 FA on transfer efficiency of EPA and DHA, treatment did not influence $(P=0.65)$ the incorporation of dietary total n-3 FA into milk fat and averaged $11.6 \pm 0.6 \%$.

\section{Intramammary LPS Challenge}

After the LPS challenge, treatment did not affect $(P$ $=0.20$ ) mean body temperature (Table 6 ). The interval from LPS infusion to peak of body temperature was longer $(P=0.07)$ for cows fed R6 than for those fed R4 or R5 (Table 6). However, the duration of elevated body temperature, based on rectal temperature $\geq 39.5^{\circ} \mathrm{C}$, did not differ among dietary treatments.

Somatic cell count in milk after the LPS challenge increased in all glands, but the increments were greater in the quarter in which LPS was infused (Figure 3A). An effect $(P=0.09)$ of diet was observed for SCC: cows fed R4 and R6 had lower SCC in milk compared with those fed R5 (Figure 3A). The mean concentra- tions of insulin and glucose in plasma after LPS challenge were not different among treatments. However, cows receiving the R5 diet tended $(P=0.08)$ to have greater concentration of insulin than cows fed the R6 diet at $\mathrm{h} 4$, whereas cows fed $\mathrm{R} 6$ had greater circulating concentrations of insulin compared with those fed R4 or R5 at h 8 (Figure 3B). The mean concentrations of acid-soluble protein and haptoglobin in plasma did not differ among treatments (Table 6 and Figure 3C, respectively). Nonetheless, at $24 \mathrm{~h}$ after LPS infusion, haptoglobin peaked higher $(P<0.05)$ for cows fed R6 compared with those fed R4 or R5 (Figure 3C). Concentrations of IFN- $\gamma$ in plasma did not differ among dietary treatments; however, cows fed R4 had a smaller $(P<0.05)$ peak and attenuated concentrations of IL-6 compared with those fed R5 or R6 (Figure 3D). Dry matter intake decreased in all treatments on the day of the challenge with LPS, and the decline averaged 2 $\mathrm{kg} / \mathrm{d}$ or $8.3 \%$ of the previous day's intake (Figure $3 \mathrm{E}$ ). Intake recovered by $2 \mathrm{~d}$ after the challenge. Milk yield also declined during the LPS challenge in all treatments 
Table 5. Effect of altering the ratio of dietary n-6 to n-3 FA on milk FA profile

\begin{tabular}{|c|c|c|c|c|c|}
\hline \multirow[b]{2}{*}{$\mathrm{FA}, \mathrm{g} / 100 \mathrm{~g}$ of $\mathrm{FA}$} & \multicolumn{3}{|c|}{ Treatment $^{1}$} & \multirow[b]{2}{*}{ SEM } & \multirow[b]{2}{*}{$P$-value } \\
\hline & $\mathrm{R} 4$ & $\mathrm{R} 5$ & $\mathrm{R} 6$ & & \\
\hline C6:0 & 4.33 & 5.16 & 4.11 & 0.63 & 0.45 \\
\hline C8:0 & 1.10 & 1.30 & 1.13 & 0.07 & 0.12 \\
\hline C10:0 & 2.23 & 2.38 & 2.36 & 0.13 & 0.69 \\
\hline $\mathrm{C} 11: 0$ & 0.02 & 0.03 & 0.02 & 0.01 & 0.62 \\
\hline C12:0 & 2.83 & 3.01 & 3.00 & 0.16 & 0.68 \\
\hline C14:0 & 11.79 & 11.17 & 11.84 & 0.59 & 0.66 \\
\hline C14:1 trans-9 & 0.24 & 0.24 & 0.24 & 0.01 & 0.98 \\
\hline C14:1 cis-9 & 0.95 & 0.81 & 0.86 & 0.07 & 0.44 \\
\hline $\mathrm{C} 15: 0$ & $1.10^{\mathrm{a}}$ & $0.97^{\mathrm{b}}$ & $1.00^{\mathrm{ab}}$ & 0.04 & 0.10 \\
\hline $\mathrm{C} 15: 1$ trans -10 & 0.19 & 0.19 & 0.21 & 0.01 & 0.13 \\
\hline C16:0 & 38.63 & 38.05 & 36.56 & 0.96 & 0.30 \\
\hline C16:1 trans $^{2}$ & 0.10 & 0.08 & 0.08 & 0.01 & 0.38 \\
\hline C16:1 cis-9 & 0.58 & 0.50 & 0.39 & 0.08 & 0.25 \\
\hline C17:0 & 1.49 & 1.62 & 1.62 & 0.05 & 0.15 \\
\hline C18:0 & 7.24 & 8.02 & 8.39 & 0.51 & 0.29 \\
\hline C18:1 trans- 8 & 0.29 & 0.26 & 0.31 & 0.03 & 0.55 \\
\hline C18:1 trans- 9 & 0.31 & 0.31 & 0.30 & 0.04 & 0.95 \\
\hline C18:1 trans-10 & 1.28 & 0.85 & 1.06 & 0.37 & 0.73 \\
\hline C18:1 trans-11 & 1.40 & 1.32 & 1.47 & 0.12 & 0.65 \\
\hline C18:1 cis-9 & 17.27 & 17.51 & 15.23 & 1.47 & 0.47 \\
\hline $\mathrm{C} 18: 1$ cis-10 & $0.59^{\mathrm{b}}$ & $0.63^{\mathrm{ab}}$ & $0.73^{\mathrm{a}}$ & 0.04 & 0.08 \\
\hline $\mathrm{C} 18: 1$ cis-11 & $0.62^{\mathrm{a}, \mathrm{x}}$ & $0.50^{\mathrm{y}}$ & $0.48^{\mathrm{b}}$ & 0.04 & 0.05 \\
\hline C18:1 cis-12 & $0.30^{\mathrm{b}}$ & $0.39^{\mathrm{a}}$ & $0.42^{\mathrm{a}}$ & 0.02 & $<0.01$ \\
\hline C18:2 cis- 9, cis- 12 & $2.66^{\mathrm{b}}$ & $2.71^{\mathrm{b}}$ & $3.22^{\mathrm{a}}$ & 0.17 & 0.05 \\
\hline C18:2, conjugated ${ }^{2}$ & $0.14^{\mathrm{a}}$ & $0.12^{\mathrm{ab}}$ & $0.11^{\mathrm{b}}$ & 0.01 & 0.06 \\
\hline C18:3 cis- 9 , cis- 12, cis- 15 & 0.39 & 0.41 & 0.43 & 0.01 & 0.12 \\
\hline $\mathrm{C} 20: 0$ & 0.15 & 0.15 & 0.14 & 0.01 & 0.61 \\
\hline $\mathrm{C} 20: 1$ trans 11 & 0.72 & 0.66 & 0.70 & 0.07 & 0.84 \\
\hline $\mathrm{C} 20: 4$ cis-5, cis- 8, cis- 11, cis- 14 & 0.10 & 0.11 & 0.11 & 0.01 & 0.81 \\
\hline $\mathrm{C} 20: 5$ cis- 5, cis- 8, cis- 11, cis- 14, cis- 17 & $0.08^{\mathrm{a}}$ & $0.06^{\mathrm{a}}$ & $0.04^{\mathrm{b}}$ & 0.01 & $<0.01$ \\
\hline $\mathrm{C} 22: 0$ & 0.04 & 0.05 & 0.05 & 0.01 & 0.65 \\
\hline $\mathrm{C} 22: 1$ trans -11 & $0.05^{\mathrm{a}}$ & $0.03^{\mathrm{ab}}$ & $0.02^{\mathrm{b}}$ & 0.01 & 0.10 \\
\hline $\mathrm{C} 22: 5$ cis- 7, cis- 10, cis- 13, cis- 16, cis- 19 & $0.12^{\mathrm{a}}$ & $0.10^{\mathrm{b}}$ & $0.07^{\mathrm{c}}$ & 0.01 & 0.001 \\
\hline $\mathrm{C} 24: 1$ cis- 15 & 0.14 & 0.13 & 0.17 & 0.02 & 0.42 \\
\hline Other FA & 0.04 & 0.05 & 0.01 & 0.02 & 0.51 \\
\hline$<\mathrm{C} 16$ & 24.77 & 25.26 & 24.77 & 0.99 & 0.92 \\
\hline $\mathrm{C} 16$ & 40.53 & 39.77 & 38.13 & 0.96 & 0.20 \\
\hline$>\mathrm{C} 16$ & 34.65 & 34.92 & 37.09 & 1.34 & 0.37 \\
\hline Total SFA & 70.13 & 70.92 & 69.23 & 1.44 & 0.70 \\
\hline Total MUFA & 26.31 & 25.50 & 26.77 & 1.30 & 0.77 \\
\hline Total PUFA & 3.52 & 3.53 & 3.99 & 0.19 & 0.15 \\
\hline Total n-6 & $2.90^{\mathrm{b}}$ & $3.13^{\mathrm{ab}}$ & $3.45^{\mathrm{a}}$ & 0.14 & 0.03 \\
\hline Total n-3 & 0.62 & 0.60 & 0.54 & 0.03 & 0.23 \\
\hline $\mathrm{n}-6$ to $\mathrm{n}-3$ ratio & $4.74^{\mathrm{c}}$ & $5.41^{\mathrm{b}}$ & $6.37^{\mathrm{a}}$ & 0.16 & $<0.001$ \\
\hline
\end{tabular}

(Figure 3F); however, the decrease in production occurred on the day after the challenge. The decline in milk yield was of $4.7 \mathrm{~kg} / \mathrm{d}$, which represents $11.5 \%$ of the production in the day preceding the challenge.

\section{DISCUSSION}

Altering the ratio of n- 6 to n- 3 FA in the diet offered to early lactation dairy cows improved yields of milk and milk components, in part because of an increase in caloric intake. Cows fed the R4 diet consumed the most
DM, which, combined with the increased concentrations of n-3 FA in the FA supplement, resulted in twice as much EPA and DHA being consumed compared with those fed R6. In many reports in the literature, feeding large quantities of EPA and DHA as fish oil to dairy cows reduces DMI (Donovan et al., 2000), but incorporation of moderate amounts of EPA and DHA from fish oil as Ca salts has no effect on intake of dairy cows (Juchem et al., 2008). Some researchers have attributed the decrease in DMI when PUFA are fed to the ability of these FA to stimulate release of gut 
Table 6. Body temperature, plasma concentrations of hormones, metabolites, cytokines, and acute phase proteins, and blood neutrophil activity of lactating Holstein cows receiving diets varying in the ratio of n- 6 to n-3 fatty acids after an intramammary challenge with LPS

\begin{tabular}{|c|c|c|c|c|c|c|c|}
\hline \multirow[b]{2}{*}{ Item } & \multicolumn{3}{|c|}{ Treatment $^{1}$} & \multirow[b]{2}{*}{ SEM } & \multicolumn{3}{|c|}{$P$-value ${ }^{2}$} \\
\hline & $\mathrm{R} 4$ & $\mathrm{R} 5$ & $\mathrm{R} 6$ & & Trt & Hour & Trt $\times$ Hour \\
\hline Temperature, ${ }^{\circ} \mathrm{C}$ & 39.06 & 39.26 & 39.12 & 0.08 & 0.20 & $<0.001$ & $<0.01$ \\
\hline Peak temperature,${ }^{3} \mathrm{C}$ & 40.80 & 41.33 & 40.78 & 0.21 & 0.14 & - & - \\
\hline Time to peak temperature, ${ }^{3} \mathrm{~h}$ & $5.08^{\mathrm{y}}-\mathrm{r}$ & $4.83^{\mathrm{y}}$ & $6.23^{\mathrm{x}}$ & 0.66 & 0.07 & - & - \\
\hline Duration temperature $\geq 39.5^{\circ} \mathrm{C},{ }^{3} \mathrm{~h}$ & 4.69 & 5.92 & 6.15 & 0.84 & 0.43 & - & - \\
\hline Glucose, $\mathrm{mg} / \mathrm{dL}$ & 65.70 & 68.77 & 66.69 & 1.68 & 0.42 & $<0.001$ & 0.39 \\
\hline Acid-soluble protein, $\mu \mathrm{g} / \mathrm{mL}$ & 50.87 & 50.67 & 50.44 & 5.03 & 0.99 & $<0.001$ & 0.77 \\
\hline Interferon- $\gamma, \mathrm{pg} / \mathrm{mL}$ & 10.33 & 29.92 & 17.85 & 8.99 & 0.36 & 0.001 & 0.93 \\
\hline Phagocytosis, \% & 53.41 & 54.93 & 52.53 & 2.40 & 0.77 & 0.40 & 0.80 \\
\hline Oxidative burst, $\%$ & 28.93 & 29.91 & 30.96 & 2.64 & 0.86 & 0.04 & 0.89 \\
\hline
\end{tabular}

${ }_{\mathrm{x}, \mathrm{y}}$ Values with different superscripts within a row represent differences among treatments $(0.05<P<0.10)$.

${ }^{1}$ Treatments represent the ratio between n- 6 to n- 3 FA in the diet. R4 is a ratio of 3.9 parts of n- 6 to 1 part of $\mathrm{n}-3$; R5 is a ratio of 4.9 parts of $\mathrm{n}-6$ to 1 part of $\mathrm{n}-3$; $\mathrm{R} 6$ is a ratio of 5.9 parts of $\mathrm{n}-6$ to 1 part of n-3.

${ }^{2}$ Trt $=$ effect of treatment; Hour $=$ effect time in hours relative to LPS infusion; Trt $\times$ Hour $=$ effect of the interaction between Trt and Hour.

${ }^{3}$ Peak temperature $=$ highest body temperature after the LPS infusion; Time to peak temperature $=$ time after LPS infusion cows reached the greatest body temperature; Duration of temperature $\geq 39.5^{\circ} \mathrm{C}=$ hours in which cows had body temperature $\geq 39.5^{\circ} \mathrm{C}$.

peptides (Bradford et al., 2008; Alizadeh et al., 2012) or to a potential increase in hepatic oxidation (Mashek et al., 2002), both of which have been linked to satiety (Allen et al., 2009). However, in the present study, all diets were supplemented with the same amount of $\mathrm{Ca}$ salts of FA, $1.43 \%$ of dietary DM, and the diets had similar concentrations of PUFA. Others have reported that moderate amounts of unsaturated FA from fish oil fed as Ca salts do not have a negative effect on DMI (Juchem et al., 2008). In fact, feeding moderate amounts of supplemental FA as Ca salts containing fish oil FA, in some cases, increases DMI compared with cows fed no supplemental fat (Moussavi et al., 2007).

Decreasing the ratio of $n-6$ to $n-3$ FA in the diet enhanced milk yield. A portion of the increased milk yield was attributed to the increase in caloric intake. Others reported an increase in milk yield when $\mathrm{n}-3$ FA were supplemented to the diets of early lactation dairy cows as Ca salts of fish oil, and a portion of the response in production was attributed to the increased DMI (Moussavi et al., 2007). In the current study, cows fed R4 produced $4.6 \mathrm{~kg}$ more $3.5 \%$ FCM compared with those fed R6 and they also consumed $1.4 \mathrm{~kg}$ more DM per day. At $1.62 \mathrm{Mcal} / \mathrm{kg}$ of diet, the additional DMI provided sufficient calories $(2.27 \mathrm{Mcal})$ for approximately $3.3 \mathrm{~kg}$ of milk, which contained $0.69 \mathrm{Mcal} / \mathrm{kg}$. Therefore, $1.3 \mathrm{~kg}$ of milk cannot be accounted for in the differences in DM and nutrient intakes. It is possible that altering the dietary ratio of n- 6 to n- 3 FA, which resulted in changes in tissue FA composition, influenced nutrient partitioning and favored lactation. Others have reported that changes in the supply of dietary n-3 FA increased the concentrations of these $\mathrm{FA}$ in different tissues (Bilby et al., 2006b). Feeding n-3 FA resulted in increased incorporation into the hepatic tissue, which altered hepatic expression of the gluconeogenic enzymes pyruvate carboxylase and phosphoenol pyruvate carboxykinase (Amaral, 2008). In fact, Amaral (2008) reported that changes in hepatic mRNA abundance for gluconeogenic enzymes were accompanied by a more rapid increase in IGF-1 concentrations in plasma of cows in early lactation. Likewise, Bilby et al. (2006a) reported altered responsiveness to exogenous bST by preferentially increasing growth hormone and reducing IGF-1 concentrations in plasma, and also greater milk production by cows fed fish oil compared with those fed cottonseed. Thus, changes in the FA profile of tissues such as liver could influence synthesis and metabolism of other nutrients and affect lactation performance. Improving hepatic gluconeogenesis would favor lactose synthesis in the mammary gland and, potentially, yield of milk.

The concentration of milk components was not altered by treatment, but because of the increased milk yield, the yields of fat, true protein and lactose increased as the dietary ratio of n-6 to n-3 FA decreased. A concern of feeding PUFA is the risk of milk fat depression. The latter can be exacerbated when PUFA present in fish oil replace linoleic or linolenic acids in the diet (Whitlock et al., 2002). In many instances, feeding PUFA induces a reduction in concentrations of fat and protein in milk (Rabiee et al., 2012), although the effects on yields of these milk components are not necessarily negative. It is known that negative associative effects exist between dietary ingredients that can influence concentration of milk components (Onetti and Grummer, 2004). In gen- 

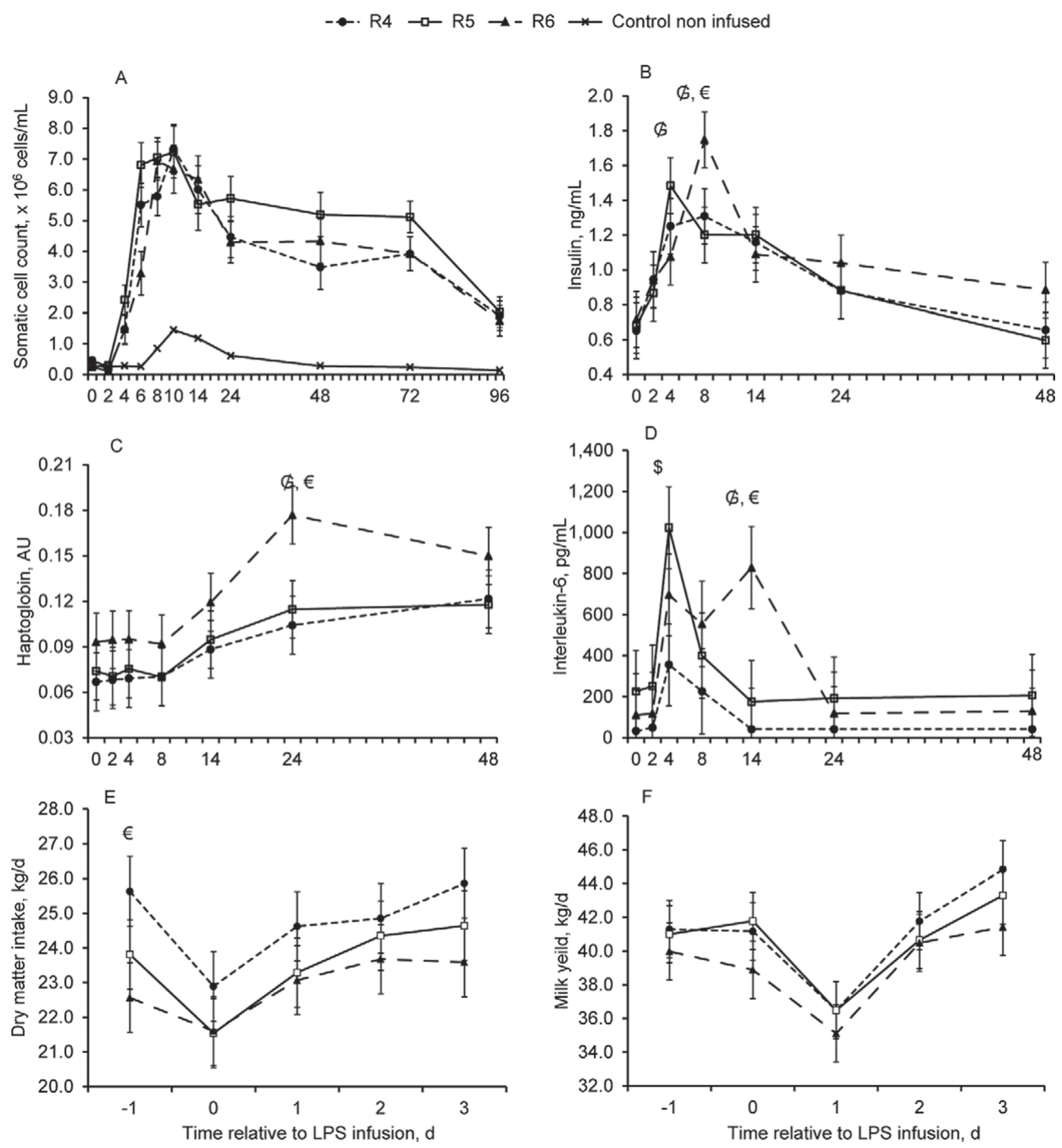

Figure 3. Somatic cell count in milk $\left(\mathrm{A} ; \mathrm{R} 4=3.68, \mathrm{R} 5=4.33\right.$, and $\mathrm{R} 6=3.58 \pm 0.25 \times 10^{6} / \mathrm{mL}$; effect of treatment: $P=0.09$; interaction between treatment and hour: $P=0.07$; R4 vs. R5: $P=0.08$; R4 vs. R6: $P=0.78$; R5 vs. R6: $P=0.04)$, and concentrations of insulin (B; R4 $=$ $0.94, \mathrm{R} 5=0.94$, and $\mathrm{R} 6=1.03 \pm 0.08 \mathrm{ng} / \mathrm{mL}$; effect of treatment: $P=0.66$; interaction between treatment and hour: $P=0.24)$, haptoglobin $(\mathrm{C} ; \mathrm{R} 4=0.08, \mathrm{R} 5=0.09$, and $\mathrm{R} 6=0.11 \pm 0.02$ optical density; effect of treatment: $P=0.30$; interaction between treatment and hour: $P=$ 0.57 ), and IL-6 (D; R4 = 112.5, R5 $=353.4$, and $\mathrm{R} 6=365.1 \pm 86.6 \mathrm{pg} / \mathrm{mL}$; effect of treatment: $P=0.07$; interaction between treatment and hour: $P=0.57$; R4 vs. R5: $P=0.05$; R4 vs. R6: $P=0.04$; R5 vs. R6: $P=0.92)$ in plasma, DMI $(\mathrm{E} ; \mathrm{R} 4=24.8, \mathrm{R} 5=23.5$, and R6 $=22.9 \pm$ $0.7 \mathrm{~kg} / \mathrm{d}$; effect of treatment: $P=0.21$; interaction between treatment and day: $P=0.94)$, and milk yield $(\mathrm{F} ; \mathrm{R} 4=41.1, \mathrm{R} 5=40.6$, and $\mathrm{R} 6=$ $39.2 \pm 1.2 \mathrm{~kg} / \mathrm{d}$; effect of treatment: $P=0.48$; interaction between treatment and day: $P=0.96$ ) of lactating Holstein cows fed 3.9 to 1 (R4), 4.9 to 1 (R5), and 5.9 to 1 (R6) ratio of n- 6 to n-3 FA in the diet. Milk and blood samples were collected immediately before (h 0) and then after an intramammary challenge with $10 \mu \mathrm{g}$ of Escherichia coli LPS. Dry matter intake and milk yield are represented for the day before (d $-1)$, the day of challenge $(\mathrm{d} 0)$, and $3 \mathrm{~d}$ after the challenge. Within an hour or day, pairwise differences $(P<0.05)$ are represented as follow: $\$$ (R4 vs. R5), € (R4 vs. R6), or G (R5 vs. R6).

eral, feeding fat sources rich in unsaturated FA is more detrimental to milk fat concentration when the dietary concentration of NDF is low or when the main forage source is corn silage compared with alfalfa (Smith et al., 1993). In the current study, all diets had similar unsaturated FA concentration, and diets were formulated to contain more than sufficient NDF (NRC, 2001), and limited starch, although the caloric density of rations were typical of high yielding dairy cows. In fact, results from all 3 diets indicated reasonable milk fat concentrations and excellent yields of $3.5 \%$ FCM, indicating that milk fat depression was not an issue. Feeding fish oil FA can pose a risk for milk fat depression, which is accompanied by increased proportions of CLA and trans 
C18:1 FA in milk (Donovan et al., 2000). Nevertheless, the concentration of trans-10 C18:1 in milk fat was not altered by diet, but concentration of CLA increased with feeding R4. It is likely that either the similar amounts of unsaturated FA consumed by cows from the 3 experimental diets or the provision of sufficient dietary NDF limited the potentially negative associative effects of feeding fish oil FA on milk components.

Despite the doubling in intake of EPA and DHA by cows fed R4 compared with those fed R6, the FA profile of milk fat did not reflect shifts compatible with a decline in de novo synthesis of FA. Diets that induce milk fat depression usually result in accumulation of certain trans FA in milk fat and are characterized by a reduction in the proportion of short- and mediumchain FA in milk (Bauman et al., 2011). As observed in other studies (Gonthier et al., 2005; Petit et al., 2007), the differences in the proportions of PUFA in milk fat reflected the differences in dietary FA composition. Consequently, as the ratio of n- 6 to n- 3 FA in the diet changed, so did that of milk fat. The transfer efficiency of PUFA from the diet to the mammary gland in the present study was greater than the efficiency reported by others (Gonthier et al., 2005). It is possible that the extent of biohydrogenation of PUFA was less, which would have provided a larger proportion of the consumed FA in their original form for absorption in the small intestine. Interestingly, the transfer efficiency of EPA or DHA was affected by diet, with the lowest efficiency observed for cows fed R6, which provided, on average, only $10 \mathrm{~g} / \mathrm{d}$ of these FA. The efficiency of transfer achieved a maximum and then reached a plateau as cows consumed approximately $15 \mathrm{~g} / \mathrm{d}$ of EPA and DHA combined in R5, with no further increase with feeding $20 \mathrm{~g} / \mathrm{d}$ of EPA/DHA in d R4. It is possible that a larger proportion of the EPA and DHA absorbed by cows fed R6 was used for metabolic functions that prevented them from being secreted into milk fat.

Plasma FA profile partly reflects the profile of FA reaching the duodenum and eventually absorbed (Gonthier et al., 2004, 2005). Ruminal biohydrogenation limits the supply of unsaturated FA for absorption in ruminants. However, the extent to which unsaturated FA were biohydrogenated in the current study did not prevent n- 6 and n-3 FA from being absorbed and detected in plasma in concentrations that paralleled those fed in the diet. Consequently, the major differences detected in the plasma profile of FA were analogous to the differences in the supply of dietary FA.

Energy balance increased as the ratio of dietary n-6 to n-3 FA increased. Generally, feeding fat to early lactation cows does not improve energy balance and, in many cases, fat supplementation improves milk yield with either no changes or slight decreases in DMI, which reduces energy balance (Staples et al., 1998). Feeding increasing amounts of n-3 FA improved milk yield and tended to improve feed conversion ratio, which resulted in more ingested calories partitioned into milk calories. These results suggest that cows fed diets with a greater proportion of n-3 FA had improved partitioning of nutrients toward milk synthesis instead of restoring body tissues. A similar response is often observed when cows are fed supplemental fat compared with no fat supplementation (Rabiee et al., 2012). In the rodent model, increasing the consumption of $n-3$ FA is reported to reduce fat deposition in spite of similar caloric intake, reinforcing the role of FA in altering nutrient partitioning (Buckley and Howe, 2010). A more pronounced negative energy balance is frequently associated with greater tissue mobilization (Petit et al., 2007). Although energy balance was slightly but significantly less for cows fed R4 compared with R6, differences in BW, BCS, and concentrations of metabolites and hormones that can be indicative of energetic status were negligible. At the end of the 13-wk experiment, BW and BCS differed only by $7 \mathrm{~kg}$ and 0.1 unit, respectively. Therefore, the increased secretion of milk calories did not seem to occur at the expense of body reserves. An additional explanation for improved feed efficiency is that feeding more $n-6$ relative to $n-3$ FA resulted in increased nutrient expenditure to maintain a more proinflammatory state (Colditz, 2002). Feeding n-6 FA has the potential to enhance the proinflammatory state (Calder, 2012), and cows fed the R6 diet had increased markers of inflammation. Under acute inflammation, amino acids and other nutrients are partitioned away from storage and growth and used to maintain immune function (Gifford et al., 2012). Klasing and Calvert (1999) estimated that lysine utilization by the immune system of poultry increased 5-fold during LPS induced inflammation. Induction of inflammatory response in feed-restricted steers increased splanchnic tissue utilization of amino acids by $2.67 \mathrm{~mol} / \mathrm{d}$ (Burciaga-Robles, 2009). These differences in amino acid utilization were independent of the effects of inflammation on appetite. These data illustrate the shift in nutrient utilization and some of the metabolic costs of mounting an inflammatory response. Therefore, we hypothesize that altering the diet might have altered the inflammatory state of cows that could influence nutrient use (Colditz, 2002; Gifford et al., 2012).

Increased intake of n-3 FA by cows fed the R4 diet attenuated the inflammatory response induced by the intramammary infusion of LPS. Acute inflammation can induce tissue insulin resistance, which could be accompanied by increased glycogenolysis and gluconeogenesis (Vernay et al., 2012). Ballou et al. (2009) supplemented the diet of dairy cows during the transition period with 
either fish oil or a source of mostly saturated free FA. Mammary glands were then challenged with $100 \mu \mathrm{g}$ of $E$. coli LPS, a dose 10-fold greater than that used in the present study. Those authors were unable to detect any attenuation of the local or systemic acute phase responses by the source of dietary FA fed (Ballou et al., 2009). The discrepancies between the findings of Ballou et al. (2009) and those of the current study, in which some attenuation of the inflammatory response was observed with $\mathrm{R} 4$, might be related to the dose of LPS used or, perhaps, the amount of EPA and DHA absorbed and incorporated into tissues, or the ratio of n-3 to n-6 FA. Ballou et al. (2009) fed a much greater dose of EPA + DHA, $60 \mathrm{~g} / \mathrm{d}$ pre- and $45 \mathrm{~g} / \mathrm{d}$ postpartum, which was 2 - to 3 -fold the intake by $\mathrm{R} 4$ cows.

Decreasing the ratio of n- 6 to n-3 FA in the diet of cows from R6 to R4 probably altered the FA profile of membrane phospholipids in the immune cells (Silvestre et al., 2011). It is expected that the observed changes in plasma FA profile with the different diets also influenced the FA composition of cell membrane in leukocytes. Silvestre et al. (2011) demonstrated that feeding fish oil reduced inflammatory cytokine production by PMNL. In cell culture (Huang et al., 2010) and in rodent models (Vijay-Kumar et al., 2011), n-3 FA consistently reduced the inflammatory response to LPS. Therefore, n-3 FA have the ability to modulate the inflammatory response as observed after the LPS challenge, although altering the supply of dietary n-3 FA will not necessarily protect from the deleterious effects of an excessive acute phase response (Ballou et al., 2009). In fact, altering the ratio of FA in the diet did not attenuate the losses in DMI and milk yield during the LPS challenge in the current study. In addition, during the challenge, the loss in milk production of $4.7 \mathrm{~kg} / \mathrm{d}$ represented approximately $3.20 \mathrm{Mcal}$, which matches the reduction in caloric consumption due to the $2 \mathrm{~kg} / \mathrm{d}$ decline in DMI (3.24 Mcal).

\section{CONCLUSIONS}

Decreasing the ratio of n- 6 to n- 3 FA in the diet of lactating dairy cows while maintaining similar dietary concentrations of total FA improved productive performance in early lactation. A dietary n-6 to n-3 ratio of approximately 4:1 resulted in the greatest DMI and production of milk and milk components. Approximately $1.3 \mathrm{~kg}$ of milk response could not be accounted for by differences in nutrient intake, which suggests that reducing the dietary FA ratio from 6:1 to 4:1 can influence nutrient partitioning to favor an increased proportion of the total net energy consumed allocated to milk synthesis. Although cows fed the lowest ratio of dietary n-6 to n-3 FA had reduced energy balance, other indicators of energy status such as changes in BW, BCS, and circulating concentrations of metabolites and hormones linked to energy status were mostly unaltered. Collectively, these results indicate that improvements in lactation performance were not at the expense of body reserves. Feeding more n- 3 and less n- 6 FA in the R4 diet attenuated the acute phase response after the intramammary challenge with LPS, although the diet did not reduce losses in intake and production during the inflammatory challenge. Improvements in lactation performance by feeding diets that differ in FA profile might be related to altered nutrient partitioning by attenuating inflammatory responses.

\section{ACKNOWLEDGMENTS}

The authors thank Sergei Sennikov, Eric Diepersloot, and Grady Byers from the University of Florida (Gainesville) for assistance with the experiment. Thanks to Nishanth Tharayil and Tom Jenkins from Clemson University (Clemson, SC) for assistance with fatty acid analysis. Partial financial support for this experiment was provided by Virtus Nutrition LLC (Corcoran, CA).

\section{REFERENCES}

Alizadeh, A. R., M. Alikhani, G. R. Ghorbani, H. R. Rahmani, L. Rashidi, and J. J. Loor. 2012. Effects of feeding roasted safflower seeds (variety IL-111) and fish oil on dry matter intake, performance and milk fatty acid profiles in dairy cattle. J. Anim. Physiol. Anim. Nutr. (Berl.) 96:466-473.

Allen, M. S., B. J. Bradford, and M. Oba. 2009. Board Invited Review: The hepatic oxidation theory of the control of feed intake and its application to ruminants. J. Anim. Sci. 87:3317-3334.

Amaral, B. C. 2008. Effect of supplemental fat source on production, immunity, hepatic gene expression, and metabolism of periparturient dairy cows. PhD Diss. Department of Animal Sciences, University of Florida, Gainesville.

Badinga, L., R. J. Collier, W. W. Thatcher, C. J. Wilcox, H. H. Head, and F. W. Bazer. 1991. Ontogeny of hepatic bovine growth hormone receptors in cattle. J. Anim. Sci. 69:1925-1934.

Ballou, M. A., R. C. Gomes, and E. J. DePeters. 2009. Supplemental fish oil does not alter immune competence or the pathophysiological response to an intramammary infusion of endotoxin in peripartum multiparous Holstein cows. J. Dairy Res. 76:165-172.

Bauman, D. E., K. J. Harvatine, and A. L. Lock. 2011. Nutrigenomics, rumen-derived bioactive fatty acids, and the regulation of milk fat synthesis. Annu. Rev. Nutr. 31:299-319.

Bilby, T. R., T. Jenkins, C. R. Staples, and W. W. Thatcher. 2006b. Pregnancy, bovine somatotropin, and dietary n-3 fatty acids in lactating dairy cows: III. Fatty acid distribution. J. Dairy Sci. 89:3386-3399

Bilby, T. R., A. Sozzi, M. M. Lopez, F. T. Silvestre, A. D. Ealy, C. R. Staples, and W. W. Thatcher. 2006a. Pregnancy, bovine somatotropin, and dietary n-3 fatty acids in lactating dairy cows: I. Ovarian, conceptus, and growth hormone-insulin-like growth factor system responses. J. Dairy Sci. 89:3360-3374.

Bradford, B. J., K. J. Harvatine, and M. S. Allen. 2008. Dietary unsaturated fatty acids increase plasma glucagon-like peptide- 1 and cholecystokinin and may decrease pre-meal ghrelin in lactating dairy cows. J. Dairy Sci. 91:1443-1450.

Buckley, J. D., and P. R. C. Howe. 2010. Long-chain omega-3 polyunsaturated fatty acids may be beneficial for reducing obesity - A review. Nutrients 2:1212-1230. 
Burciaga-Robles, L. O. 2009. Effects of bovine respiratory disease on immune response, animal performance, nitrogen balance, and blood and nutrient flux across the portal drained viscera in beef steers. PhD Diss. Department of Animal Sciences, Oklahoma State University, Stillwater.

Calder, P. C. 2012. Long-chain fatty acids and inflammation. Proc. Nutr. Soc. 71:284-289.

Cheung, K., and B. Morris. 1984. The respiration and energy metabolism of sheep lymphocytes. Aust. J. Exp. Biol. Med. Sci. 62:671-685.

Colditz, I. G. 2002. Effects of the immune system on metabolism: implication for production and disease resistance in livestock. Livest. Prod. Sci. 75:257-268.

Coulombe, J. J., and L. Favreau. 1963. A new simple method for colorimetric determination of urea. Clin. Chem. 9:102-108.

Donovan, D. C., D. J. Schingoethe, R. J. Baer, J. Ryali, A. R. Hippen, and S. T. Franklin. 2000. Influence of dietary fish oil on conjugated linoleic acid and other fatty acids in milk fat from lactating dairy cows. J. Dairy Sci. 83:2620-2628.

Elanco Animal Health. 2009. The 5-point body condition scoring system. Bulletin AI 10752. Elanco Animal Health, Greenfield, IN.

Ferguson, J. D., D. T. Galligan, and N. Thomsen. 1994. Principal descriptors of body condition score in Holstein cows. J. Dairy Sci. 77:2695-2703.

Gifford, C. A., B. P. Holland, R. L. Mills, C. L. Maxwell, J. K. Farney, S. J. Terrill, D. L. Step, C. J. Richards, L. O. Burciaga Robles, and C. R. Krehbiel. 2012. Impacts of inflammation on cattle growth and carcass merit. J. Anim. Sci. 90:1438-1451.

Gochman, N., and J. M. Schmitz. 1972. Application of a new peroxide indicator reaction to the specific automated determination of glucose with glucose oxidase. Clin. Chem. 18:943-950.

Gonthier, C., A. F. Mustafa, R. Berthiaume, H. V. Petit, and D. R. Ouellet. 2004. Feeding micronized and extruded flaxseed to dairy cows: Effects on digestion and ruminal biohydrogenation of longchain fatty acids. Can. J. Anim. Sci. 84:705-711.

Gonthier, C., A. F. Mustafa, D. R. Ouellet, P. Y. Chouinard, R. Berthiaume, and H. V. Petit. 2005. Feeding micronized and extruded flaxseed to dairy cows: Effects on blood parameters and milk fatty acid composition. J. Dairy Sci. 88:748-756.

Harvatine, K. J., and M. S. Allen. 2006. Effects of fatty acid supplements on milk yield and energy balance of lactating dairy cows. J. Dairy Sci. 89:1081-1091.

Huang, L. S., N. D. Hung, D. Sok, and M. R. Kim. 2010. Lysophosphatidylcholine containing docosahexaenoic acid at the sn- 1 position is anti-inflammatory. Lipids 45:225-236.

Johnson, M. M., and J. P. Peters. 1993. Technical note: An improved method to quantify nonesterified fatty acids in bovine plasma. J. Anim. Sci. 71:753-756.

Juchem, S. O., J. E. P. Santos, R. L. A. Cerri, R. C. Chebel, K. N. Galvão, R. Bruno, and E. J. DePeters. 2008. Effect of calcium salts of fish and palm oils on lactational performance of Holstein cows. Anim. Feed Sci. Technol. 140:18-38.

Klasing, K. C., and C. C. Calvert. 1999. The care and feeding of an immune system: An analysis of lysine needs. Pages 253-264 in Proc. 8th Int. Symp. Protein Metabolism and Nutrition, Aberdeen, Scotland. G. E. Lobley, A. White, and J. C. Macrae, ed. Wageningen Academic Publishers, Wageningen, the Netherlands.

Kramer, J. K. G., V. Feliner, M. E. R. Dugan, F. D. Sauer, M. M. Mossoba, and M. P. Yarawecz. 1997. Evaluating acid and base catalysts in the methylation of milk and rumen fatty acids with special emphasis on conjugated dienes and total trans fatty acids. Lipids 32:1219-1228.

Kumar, A., Y. Takada, A. M. Boriek, and B. B. Aggarwal. 2004. Nuclear factor-кB: Its role in health and disease. J. Mol. Med. 82:434-448.

Makimura, S., and N. Suzuki. 1982. Quantitative determination of bovine serum haptoglobin and its elevation in some inflammatory diseases. Jpn. J. Vet. Sci. 44:15-21.

Marsh, W. H., B. Fingerhut, and H. Miller. 1965. Automated and manual direct methods for the determination of blood urea. J. Clin. Chem. 6:624-627.
Martinez, N., C. A. Risco, F. S. Lima, R. S. Bisinotto, L. F. Greco, E. S. Ribeiro, F. Maunsell, K. Galvão, and J. E. P. Santos. 2012. Evaluation of peripartal calcium status, energetic profile, and neutrophil function in dairy cows at low or high risk of developing uterine disease. J. Dairy Sci. 95:7158-7172.

Mashek, D. G., S. J. Bertics, and R. R. Grummer. 2002. Metabolic fate of long-chain unsaturated fatty acids and their effects on palmitic acid metabolism and gluconeogenesis in bovine hepatocytes. J. Dairy Sci. 85:2283-2289.

Moussavi, A. R. H., R. O. Gilbert, T. R. Overton, D. E. Bauman, and W. R. Butler. 2007. Effects of feeding fish meal and n-3 fatty acids on milk yield and metabolic responses in early lactating dairy cows. J. Dairy Sci. 90:136-144.

NRC. 2001. Nutrient Requirements of Dairy Cattle. 7th rev. ed. Natl. Acad. Sci., Washington. DC.

O'Fallon, J. V., J. R. Busboom, M. L. Nelson, and C. T. Gaskins. 2007. A direct method for fatty acid methyl ester synthesis: Application to wet meat tissues, oils, and feedstuffs. J. Anim. Sci. 85:1511-1521.

Onetti, S. G. and R. R. Grummer. 2004. Response of lactating cows to three supplemental fat sources as affected by forage in the diet and stage of lactation: A meta-analysis of literature. Anim. Feed Sci. Technol. 115:65-82.

Papadopoulos, G. A., D. G. D. Maes, S. van Weyenberg, T. A. T. G. van Kempen, J. Buyse, and G. P. J. Janssens. 2009. Peripartal feeding strategy with different n-6:n-3 ratios in sows: Effects on sows' performance, inflammatory and periparturient metabolic parameters. Br. J. Nutr. 101:348-357.

Petit, H. V., M. F. Palin, and L. Doepel. 2007. Hepatic lipid metabolism in transition dairy cows fed flaxseed. J. Dairy Sci. 90:47804792 .

Rabiee, A. R., K. Breinhild, W. Scott, H. M. Golder, E. Block, and I. J. Lean. 2012. Effect of fat additions to diets of dairy cattle on milk production and components: A meta-analysis and metaregression. J. Dairy Sci. 95:3225-3247.

Silvestre, F. T., T. S. Carvalho, P. C. Crawford, J. E. P. Santos, C. R. Staples, T. Jenkins, and W. W. Thatcher. 2011. Effects of differential supplementation of fatty acids during the peripartum and breeding periods of Holstein cows: II. Neutrophil fatty acids and function, and acute phase proteins. J. Dairy Sci. 94:2285-2301.

Smith, W. A., B. Harris Jr., H. H. Van Horn, and C. J. Wilcox. 1993 Effects of forage type on production of dairy cows supplemented with whole cottonseed, tallow, and yeast. J. Dairy Sci. 76:205215

Smits, E., C. Burvenich, and R. Heyneman. 1997. Simultaneous flow cytometric measurement of phagocytotic and oxidative burst activity of polymorphonuclear leukocytes in whole bovine blood. Vet. Immunol. Immunopathol. 56:259-269.

Staples, C. R., J. M. Burke, and W. W. Thatcher. 1998. Influence of supplemental fats on reproductive performance of lactating cows. J. Dairy Sci. 81:856-871.

Van Soest, P. J., J. B. Robertson, and B. A. Lewis. 1991. Methods for dietary fiber, neutral detergent fiber and non-starch polysaccharides in relation to animal nutrition. J. Dairy Sci. 74:3583-3597.

Vernay, M. C. M. B., O. Wellnitz, L. Kreipe, H. A. van Dorland, and R. M. Bruckmaier. 2012. Local and systemic responses to intramammary lipopolysaccharide challenge during long-term manipulated plasma glucose and insulin concentrations in dairy cows. J. Dairy Sci. 95:2540-2549.

Vijay-Kumar, M., S. M. Vanegas, N. Patel, J. D. Aitken, T. R. Ziegler, and V. Ganji. 2011. Fish oil rich diet in comparison to saturated fat rich diet offered protection against lipopolysaccharide-induced inflammation and insulin resistance in mice. Nutr. Metab. (Lond.) $8: 16$.

Whitlock, L. A., D. J. Schingoethe, A. R. Hippen, K. F. Kalscheur, R. J. Baer, N. Ramaswamy, and K. M. Kasperson. 2002. Fish oil and extruded soybeans fed in combination increase conjugated linoleic acids in milk of dairy cows more than when fed separately. J. Dairy Sci. 85:234-243. 